Article

\title{
Characterization of Volatile Compounds of Eleven Achillea Species from Turkey and Biological Activities of Essential Oil and Methanol Extract of $\boldsymbol{A}$. hamzaoglui Arabacı \& Budak
}

\section{Fatma Pinar Turkmenoglu ${ }^{1, *}$, Osman Tuncay Agar ${ }^{1}$, Galip Akaydin ${ }^{2}$, Mutlu Hayran ${ }^{3}$ and Betul Demirci $^{4}$}

1 Department of Pharmaceutical Botany, Faculty of Pharmacy, Hacettepe University, Ankara 06100, Turkey; E-Mail: tagar@hacettepe.edu.tr

2 Department of Biology, Faculty of Education, Hacettepe University, Ankara 06800, Turkey; E-Mail: agalip@hacettepe.edu.tr

3 Department of Preventive Oncology, Cancer Institute, Hacettepe University, Ankara 06100, Turkey; E-Mail: mhayran@hacettepe.edu.tr

4 Department of Pharmacognosy, Faculty of Pharmacy, Anadolu University, Eskisehir 26470, Turkey; E-Mail: bdemirci@anadolu.edu.tr

* Author to whom correspondence should be addressed; E-Mail: fpt@hacettepe.edu.tr; Tel.: +90-312-305-1089; Fax: +90-312-311-4777.

Academic Editor: Luca Forti

Received: 9 April 2015 / Accepted: 17 June 2015 / Published: 22 June 2015

\begin{abstract}
According to distribution of genus Achillea, two main centers of diversity occur in S.E. Europe and S.W. Asia. Diversified essential oil compositions from Balkan Peninsula have been numerously reported. However, report on essential oils of Achillea species growing in Turkey, which is one of the main centers of diversity, is very limited. This paper represents the chemical compositions of the essential oils obtained by hydrodistillation from the aerial parts of eleven Achillea species, identified simultaneously by gas chromatography and gas chromatography-mass spectrometry. The main components were found to be 1,8-cineole, $p$-cymene, viridiflorol, nonacosane, $\alpha$-bisabolol, caryophyllene oxide, $\alpha$-bisabolon oxide A, $\beta$-eudesmol, 15-hexadecanolide and camphor. The chemical principal component analysis based on thirty compounds identified three species groups and a subgroup, where each group constituted a chemotype. This is the first report on the chemical composition of A. hamzaoglui essential oil; as well as the antioxidant and antimicrobial evaluation of its essential oil and methanolic extract.
\end{abstract}


Keywords: Achillea; Achillea hamzaoglui; Asteraceae; essential oil; antioxidant; antimicrobial; GC-MS; principal components analysis (PCA); hierarchical cluster analysis (HCA)

\section{Introduction}

The genus Achillea L. belongs to Asteraceae (Compositae), which is the largest family of vascular plants and distributed throughout the world. Achillea is represented by more than 140 perennial herbaceous species worldwide, and is widespread in Europe and temperate areas of Asia and in North America [1]. Forty-seven species grow in Turkey, 24 of which are endemic (51\%). Small capitula forming flat clusters at the top of the stem and hairy aromatic leaves are characteristic for the genus [2-4].

Achillea species, commonly known as "yarrow", have been used in folk medicine for thousands of years due to numerous medicinal properties. The name of Achillea originated from the name of "Achilles" from Greek mythology, as he used yarrow to treat his bleeding ankle and wounds. Today, several therapeutic applications, such as anti-inflammatory, wound healing, spasmolytic and choleretic uses, are approved by scientific experimental results $[1,5,6]$. In Turkey, various species of the genus are used in wound healing; abdominal pain; stomachache; symptomatic relief of colds, ulcer, and diarrhea; as diuretic; emmenagog; appetizer; carminative; and insecticidal agent [7-11]. Similar ethnomedicinal uses and some veterinary use of some species were also reported for many other regions in the world $[1,5,12,13]$. Besides medical applications, plants are used as spices and additives in food products, while essential oil and extracts of some species are used for preparation of digestive teas and cosmetic products. Additionally, some species are cultivated and used in gardening or as cutflowers [5,13].

The genus Achillea is rich in terpenoids and flavonoids, which are possible bioactive compounds. Monoterpenes were reported to be the major constituents of essential oil of the genus although high levels of sesquiterpenes were quantified [1,12,14]. Among the monoterpenes 1,8-cineole, found in almost every essential oil, was reported to be the most frequently identified component. Furthermore, it was also reported to be the major compound in about one third of yarrow essential oils. Compounds having bornane skeleton such as camphor and borneol were reported to be the second and third most frequently charactarized components of Achillea oil and they were described several times as major compounds. Beside $\alpha$ - and $\beta$-pinenes, monoterpenes having $p$-menthane, thujone and pinane skeletons, as mentioned, as the most frequent components have been reported. Sesquiterpenes, both hydrocarbones and oxygenated ones, have also been reported in a considerable number of species. Beside chamazulene, $\beta$-caryophyllene and its oxides, $\alpha$-bisabolol and oxides, cubebene, germacrene, eudesmol, and farnesene were characterized in yarrow oil $[5,15,16]$.

According to distribution of genus Achillea, two main centers of diversity occur in S.E. Europe and S.W. Asia [16,17]. In accordance with the great diversity in S.E. Europe, diversified essential oil compositions from the Balkan Peninsula have also been reported and revised by Radulovic et. al. [16]. However, reports on essential oils of Achillea species growing in Turkey, which is located in both S.E. Europe and S.W. Asia, and considered one of the main centers of diversity, are very limited. This is the first report on essential oil composition of A. hamzaoglui Arabac1 \& Budak, which is the most recently 
identified Achillea species in Turkey [4]. Antioxidant and antimicrobial activities of essential oil and methanolic extract of $A$. hamzaoglui were also evaluated. In this paper, we have also investigated essential oil composition of $A$. biebersteinii Afan., A. coarctata Poir., A. kotschyi Boiss. subsp. kotschyi, A. lycaonica Boiss. \& Heldr., A. millefolium L. subsp. millefolium, A. schischkinii Sosn., A. setacea Waldst. \& Kit., A. sintenisii Hub.-Mor., A. vermicularis Trin. and A. wilhelmsii C.Koch. subsp. wilhelmsii growing in Turkey, in addition to that of A. hamzaoglui, of which, A. lycaonica, A. schischkinii, A. sintenisii and A. hamzaoglui are endemic species.

\section{Results and Discussion}

\subsection{Chemical Composition}

Eleven Achillea essential oils were obtained by hydrodistillation from air dried aerial parts and subsequently analyzed by GC and GC/MS systems. One hundred seventy-six compounds were identified from Achillea oils, which constituted $76.1 \%$ to $97.8 \%$ of the total oil. Identified compounds in Achillea oils with their relative percentages are listed in Table 1.

In the oil of the $A$. biebersteinii, 55 components were characterized, representing $95.7 \%$ of the total oil. $p$-cymene (18.6\%), 1,8-cineole (16.5\%), camphor (11.7\%), hexadecanoic acid $(11.2 \%)$ and $\beta$-eudesmol (10.1\%) were found as main constituents. A. biebersteinii is distributed in S. Bulgaria, S.W. and C. Asia [2]. Literature survey revealed that studies on volatile compounds of this plant accumulated on Asian species. Variations in the essential oil composition of this species from Turkey, Iran, Jordan and Azerbaijan have been evaluated and nine groups of chemotypes were proposed by Polatogluet et al. [18]: piperitone, camphor, 1,8-cineole; 1,8-cineole, camphor; cis-ascaridole, $p$-cymene; camphor, borneol, 1,8-cineole; spathulenol; $\alpha$-terpineol, spathulenol; $p$-cymene, camphor; mixed group 1-1,8-cineole, camphor, $\alpha$-fenchene, santolinatriene; and mixed group 2-1,8-cineole, camphor, piperitone, iso-ascaridole, $p$-cymene. A. biebersteinii oil investigated in this study might be proposed as third mixed group containing $p$-cymene, 1,8-cineole, camphor, as well as high amounts of hexadecanoic acid and $\beta$-eudesmol.

A total of 28 compounds were characterized in $A$. coarctata essential oil, representing $97.3 \%$ of the total oil with viridiflorol $(25.9 \%)$, camphor (9.8\%), caryophyllene oxide $(9.6 \%), 15$-hexadecanolide (9.4\%), hexadecanoic acid (8.2\%) and $\beta$-eudesmol (7.4\%). Oxygenated monoterpenes, 1,8-cineole, camphor and borneol were reported in the essential oils of $A$. coarctata obtained from inflorescence and leaves from Greece [19]. A literature survey revealed that there is only one report on the essential oil composition of $A$. coarctata from Turkey indicating 1,8-cineole, camphor and viridiflorol as major constituents [20]. 15-Hexadecanolide and hexadecanoic acid identified in this study, were not previously reported from $A$. coarctata. 
Table 1. The composition of the essential oils of Achillea species. AB: A. biebersteinii, AC: A. coarctata, AH: A. hamzaoglui, AK: A. kotschyi subsp. kotschyi, AL: A. lycaonica, AM: A. millefolium subsp. millefolium, ASc: A. schischkinii, ASe: A. setacea, ASi: A. sintenisii, AV: A. vermicularis, and AW: A. wilhelmsii subsp. wilhelmsii.

\begin{tabular}{|c|c|c|c|c|c|c|c|c|c|c|c|c|c|c|}
\hline \multirow{2}{*}{ No } & \multirow{2}{*}{$\mathbf{R R I}^{\mathbf{a}}$} & \multirow{2}{*}{ Compound } & \multicolumn{11}{|c|}{ Content ${ }^{\mathrm{b}} \%$} & \multirow{2}{*}{$\mathbf{I M}^{\mathrm{c}}$} \\
\hline & & & $\mathbf{A B}$ & $\mathbf{A C}$ & $\mathbf{A H}$ & $\mathbf{A K}$ & $\mathbf{A L}$ & AM & ASc & ASe & $\mathbf{A S i}$ & AV & AW & \\
\hline 1 & 1014 & Tricyclene & 0.1 & - & - & - & - & - & - & - & - & - & 0.2 & MS \\
\hline 2 & 1032 & $\alpha$-Pinene & 1.2 & 0.6 & 0.5 & 1.0 & - & $\operatorname{tr}$ & 0.2 & - & - & - & 0.5 & RRI, MS \\
\hline 3 & 1035 & $\alpha$-Thujene & - & - & 0.2 & - & - & - & - & - & - & - & - & MS \\
\hline 4 & 1043 & Santolinatriene & 0.5 & - & - & - & - & - & - & - & - & - & - & MS \\
\hline 5 & 1076 & Camphene & 1.7 & 0.7 & 0.7 & 0.5 & - & 0.1 & $\operatorname{tr}$ & - & - & - & 6.1 & RRI, MS \\
\hline 6 & 1118 & $\beta$-Pinene & 0.6 & 0.6 & 1.1 & 1.4 & - & 0.1 & 0.3 & - & - & - & 0.5 & RRI, MS \\
\hline 7 & 1132 & Sabinene & - & - & 4.0 & - & - & 0.1 & 0.3 & - & - & - & - & RRI, MS \\
\hline 8 & 1188 & $\alpha$-Terpinene & - & - & 0.5 & 0.7 & - & 0.2 & 0.1 & - & - & - & - & RRI, MS \\
\hline 9 & 1195 & Dehydro-1,8-cineole & - & - & 0.1 & - & - & - & - & - & - & - & - & MS \\
\hline 10 & 1202 & 3-Hexanol & - & - & - & - & 0.4 & - & - & - & - & - & - & MS \\
\hline 11 & 1203 & Limonene & 0.2 & - & 0.1 & 0.5 & - & - & 0.1 & - & - & - & - & RRI, MS \\
\hline 12 & 1213 & 1,8-Cineole & 16.5 & 1.0 & 24.1 & 22.5 & 0.2 & 4.1 & 3.4 & 3.1 & 0.6 & - & 4.2 & RRI, MS \\
\hline 13 & 1222 & 2-Hexanol & - & - & - & - & 0.2 & - & - & - & - & - & - & MS \\
\hline 14 & 1255 & $\gamma$-Terpinene & 0.1 & - & 1.0 & 1.8 & - & 0.6 & 0.4 & - & - & - & - & RRI, MS \\
\hline 15 & 1280 & $p$-Cymene & 18.6 & 0.6 & 0.2 & 8.4 & - & 1.4 & 8.5 & - & - & - & 1.8 & RRI, MS \\
\hline 16 & 1285 & Isoamylisovalerate & - & - & 0.3 & - & - & - & - & - & - & - & 0.3 & MS \\
\hline 17 & 1290 & Terpinolene & - & - & 0.2 & - & - & - & - & - & - & - & - & RRI, MS \\
\hline 18 & 1294 & $\begin{array}{l}\text { 1,2,4-Trimethyl } \\
\text { benzene }\end{array}$ & 0.2 & - & - & - & - & - & - & - & - & - & - & MS \\
\hline 19 & 1299 & $\begin{array}{l}\text { 2-Methylbutyl } \\
\text { isovalerate }\end{array}$ & - & - & - & - & - & - & - & - & - & - & 0.2 & MS \\
\hline 20 & 1355 & $\begin{array}{l}\text { 1,2,3-Trimethyl } \\
\text { benzene }\end{array}$ & 0.2 & - & - & - & - & - & - & - & - & - & - & MS \\
\hline 21 & 1400 & Nonanal & - & - & - & - & - & - & 0.1 & - & - & - & - & MS \\
\hline 22 & 1400 & Tetradecane & - & - & - & - & - & - & - & - & - & 0.1 & - & RRI, MS \\
\hline
\end{tabular}


Table 1. Cont.

\begin{tabular}{|c|c|c|c|c|c|c|c|c|c|c|c|c|c|c|}
\hline \multirow{2}{*}{ No } & \multirow{2}{*}{$\mathbf{R R I}^{\mathbf{a}}$} & \multirow{2}{*}{ Compound } & \multicolumn{11}{|c|}{ Content ${ }^{\mathrm{b}} \%$} & \multirow{2}{*}{$\mathrm{IM}^{\mathrm{c}}$} \\
\hline & & & $\mathbf{A B}$ & $\mathbf{A C}$ & AH & AK & $\mathbf{A L}$ & AM & ASc & ASe & ASi & $\mathbf{A V}$ & AW & \\
\hline 23 & 1405 & Santolina alcohol & 1.5 & - & - & - & - & - & - & - & - & - & - & MS \\
\hline 24 & 1445 & Filifolone & 0.3 & - & - & - & - & - & 0.1 & - & - & - & - & MS \\
\hline 25 & 1474 & trans-Sabinene hydrate & - & - & 2.1 & 0.5 & - & 0.5 & 0.5 & - & - & - & 0.3 & MS \\
\hline 26 & 1495 & Bicycloelemene & - & - & - & - & - & - & 0.5 & - & - & - & - & MS \\
\hline 27 & 1497 & $\alpha$-Copaene & - & - & 0.4 & - & - & - & 0.4 & - & - & - & - & MS \\
\hline 28 & 1499 & $\alpha$-Campholene aldehyde & 0.3 & - & - & - & - & - & - & - & - & - & - & RRI, MS \\
\hline 29 & 1506 & Decanal & - & - & - & - & - & - & 0.1 & - & - & - & - & RRI, MS \\
\hline 30 & 1522 & Chrysanthenone & 1.3 & - & - & - & - & - & - & - & - & - & - & MS \\
\hline 31 & 1532 & Camphor & 11.7 & 9.8 & 6.7 & 2.8 & 1.7 & 4.0 & 1.5 & 4.1 & 0.5 & 6.7 & 41.3 & RRI, MS \\
\hline 32 & 1540 & Modhephene & - & - & - & 0.4 & - & - & - & - & - & - & - & MS \\
\hline 33 & 1547 & Dihydroachillene & 0.3 & - & - & - & - & - & - & - & - & - & 0.2 & MS \\
\hline 34 & 1553 & Linalool & 2.1 & - & 12.2 & - & - & 0.6 & 0.5 & - & - & - & - & RRI, MS \\
\hline 35 & 1556 & cis-Sabinene hydrate & - & - & 1.6 & - & 0.4 & 0.4 & 0.3 & - & - & - & 0.3 & MS \\
\hline 36 & 1571 & trans-p-Menth-2-en-1-ol & 0.4 & - & 0.2 & - & - & 0.3 & 0.1 & - & - & - & - & MS \\
\hline 37 & 1582 & cis-Chrysanthenyl acetate & - & - & - & - & 2.9 & 0.5 & - & - & 0.3 & - & - & MS \\
\hline 38 & 1586 & Pinocarvone & 0.5 & - & 0.2 & - & - & - & 0.2 & - & - & - & 0.9 & RRI, MS \\
\hline 39 & 1591 & Bornyl acetate & 0.2 & - & - & 1.3 & - & - & - & - & - & 5.1 & 1.5 & RRI, MS \\
\hline 40 & 1599 & Chrysanthenyl propionate & - & - & - & - & - & - & - & - & - & 0.1 & - & MS \\
\hline 41 & 1600 & Hexadecane & - & - & - & - & 0.3 & - & - & - & - & 0.1 & - & RRI, MS \\
\hline 42 & 1600 & $\beta$-Elemene & - & - & - & - & - & - & 0.1 & - & - & - & - & RRI, MS \\
\hline 43 & 1611 & Terpinen-4-ol & 0.3 & 0.7 & 3.4 & 1.2 & 0.6 & 2.4 & - & $\operatorname{tr}$ & - & - & 0.6 & RRI, MS \\
\hline 44 & 1612 & $\beta$-Caryophyllene & - & - & 1.5 & - & - & - & 2.8 & - & - & - & - & RRI, MS \\
\hline 45 & 1617 & Lavandulyl acetate & - & - & - & - & - & 1.1 & - & 0.9 & - & 3.3 & - & RRI, MS \\
\hline 46 & 1638 & cis-p-Menth-2-en-1-ol & 0.3 & - & 0.2 & - & - & 0.2 & 0.1 & - & - & - & - & MS \\
\hline
\end{tabular}


Table 1. Cont.

\begin{tabular}{|c|c|c|c|c|c|c|c|c|c|c|c|c|c|c|}
\hline \multirow{2}{*}{ No } & \multirow{2}{*}{$\mathbf{R R I}^{\mathbf{a}}$} & \multirow{2}{*}{ Compound } & \multicolumn{11}{|c|}{ Content b \% } & \multirow{2}{*}{ IM $^{\mathrm{c}}$} \\
\hline & & & $\mathbf{A B}$ & $\mathbf{A C}$ & $\mathbf{A H}$ & $\mathbf{A K}$ & $\mathbf{A L}$ & $\mathbf{A M}$ & ASc & ASe & $\mathbf{A S i}$ & AV & AW & \\
\hline 47 & 1648 & Myrtenal & 0.4 & - & 0.2 & - & - & - & - & 0.9 & - & - & 0.6 & MS \\
\hline 48 & 1651 & Sabinaketone & - & - & - & - & 0.4 & - & - & - & - & - & - & MS \\
\hline 49 & 1655 & Isobornyl propionate & - & - & - & - & - & - & - & - & - & - & 0.2 & MS \\
\hline 50 & 1656 & Chrysanthenylisobutyrate & - & - & - & - & - & - & - & - & - & 0.1 & - & MS \\
\hline 51 & 1661 & Alloaromadendrene & - & 0.7 & 0.2 & - & - & - & 0.4 & - & - & - & 0.3 & MS \\
\hline 52 & 1664 & Nonanol & - & - & - & - & - & - & 0.1 & - & - & - & - & MS \\
\hline 53 & 1670 & trans-Pinocarveol & 0.4 & - & - & - & 0.5 & - & 0.2 & - & - & - & 0.6 & RRI, MS \\
\hline 54 & 1678 & cis-p-Mentha-2,8-dien-1-ol & - & - & - & - & - & - & - & - & - & - & - & MS \\
\hline 55 & 1682 & $\delta$-Terpineol & 0.3 & - & 0.7 & 0.4 & - & 0.2 & 0.1 & - & - & - & 0.1 & MS \\
\hline 56 & 1683 & trans-Verbenol & - & - & 1.3 & - & 0.5 & - & - & - & - & - & 0.6 & MS \\
\hline 57 & 1686 & Lavandulol & - & - & - & - & - & 0.3 & - & - & - & - & - & RRI, MS \\
\hline 58 & 1687 & $\alpha$-Humulene & - & - & - & - & - & - & 0.4 & - & - & - & - & RRI, MS \\
\hline 59 & 1689 & trans-piperitol & 0.3 & - & - & - & - & - & - & - & - & - & - & MS \\
\hline 60 & 1688 & $\begin{array}{c}\text { Selina-4,11-diene } \\
(=4,11 \text {-Eudesmadiene })\end{array}$ & - & - & - & - & - & - & 0.1 & - & - & - & - & MS \\
\hline 61 & 1695 & $(E)-\beta$-Farnesene & - & - & 0.2 & - & - & - & - & - & - & - & - & MS \\
\hline 62 & 1700 & Heptadecane & - & - & - & - & - & - & - & - & - & 0.2 & - & RRI, MS \\
\hline 63 & 1704 & $\gamma$-Muurolene & - & - & - & - & - & - & 0.1 & - & - & - & - & MS \\
\hline 64 & 1704 & Myrtenyl acetate & - & - & - & - & - & - & - & 0.4 & - & - & - & MS \\
\hline 65 & 1705 & Fragranyl acetate & - & - & - & - & - & 1.0 & - & - & - & - & - & MS \\
\hline 66 & 1706 & $\alpha$-Terpineol & 0.6 & 1.2 & 2.9 & 1.6 & - & 2.2 & 1.5 & 0.8 & - & 0.1 & 0.2 & RRI, MS \\
\hline 67 & 1715 & Geranylformate & - & - & - & - & - & - & 0.3 & - & - & - & - & MS \\
\hline 68 & 1719 & Borneol & 0.6 & 2.1 & 0.6 & 1.0 & 0.5 & 0.4 & 0.3 & - & 1.3 & 2.5 & 6.2 & RRI, MS \\
\hline 69 & 1722 & Cabreuva oxide-II & - & - & - & - & - & - & 0.2 & - & - & - & - & MS \\
\hline
\end{tabular}


Table 1. Cont.

\begin{tabular}{|c|c|c|c|c|c|c|c|c|c|c|c|c|c|c|}
\hline \multirow{2}{*}{ No } & \multirow{2}{*}{$\mathbf{R R I}^{\mathrm{a}}$} & \multirow{2}{*}{ Compound } & \multicolumn{11}{|c|}{ Content ${ }^{\text {b } \%}$} & \multirow{2}{*}{$\mathbf{I M}^{\mathrm{c}}$} \\
\hline & & & $\mathbf{A B}$ & $\mathrm{AC}$ & $\mathbf{A H}$ & AK & $\mathbf{A L}$ & AM & ASc & ASe & $\mathbf{A S i}$ & $\mathbf{A V}$ & AW & \\
\hline 70 & 1726 & Germacrene D & 0.1 & - & 6.2 & - & - & - & 0.2 & - & - & 0.1 & - & MS \\
\hline 71 & 1733 & Neryl acetate & - & - & - & - & - & 0.3 & - & - & - & 0.6 & - & RRI, MS \\
\hline 72 & 1740 & $\alpha$-Muurolene & - & - & - & - & - & - & 0.2 & - & - & - & - & MS \\
\hline 73 & 1742 & $\beta$-Selinene & - & - & - & - & - & - & - & 1.0 & 0.3 & - & 0.4 & MS \\
\hline 74 & 1743 & Chrysanthenyl isovalerate I & - & - & - & - & 0.4 & - & - & - & - & 4.8 & - & ,MS \\
\hline 75 & 1748 & Piperitone & 1.3 & - & - & - & - & - & 1.4 & - & - & - & - & RRI, MS \\
\hline 76 & 1755 & Bicyclogermacrene & - & - & 2.8 & - & - & - & 0.2 & - & - & - & - & MS \\
\hline 77 & 1758 & cis-Piperitol & 0.3 & - & - & 0.5 & - & 0.2 & 0.2 & - & - & - & - & MS \\
\hline 78 & 1760 & Chrysanthenylisovalerate II & - & - & - & - & - & - & - & - & - & 3.3 & - & MS \\
\hline 79 & 1764 & cis-Chrysanthenol & - & - & - & - & 2.9 & 1.5 & - & - & - & - & - & MS \\
\hline 80 & 1768 & Cabreuva oxide-IV & - & - & - & - & - & - & 0.2 & - & - & - & - & MS \\
\hline 81 & 1770 & Isobornylisovalerate & - & - & - & - & - & - & - & - & - & - & 0.6 & MS \\
\hline 82 & 1773 & $\delta$-Cadinene & - & - & 0.2 & - & - & 1.4 & 0.2 & - & - & - & - & MS \\
\hline 83 & 1776 & $\gamma$-Cadinene & - & - & - & - & 0.5 & - & 0.1 & - & - & 0.1 & - & MS \\
\hline 84 & 1783 & $\beta$-Sesquiphellandrene & - & - & - & - & - & - & - & - & - & 0.1 & - & MS \\
\hline 85 & 1786 & ar-Curcumene & - & - & - & - & - & - & - & 0.2 & - & 1.3 & - & MS \\
\hline 86 & 1786 & Aromadendra-1(10),4(15)-diene & - & - & - & - & - & - & 0.6 & - & - & - & - & MS \\
\hline 87 & 1800 & Octadecane & - & - & - & - & - & - & - & - & - & 0.1 & - & RRI, MS \\
\hline 88 & 1802 & Cumin aldehyde & 0.6 & - & - & 0.6 & - & - & 0.2 & - & - & - & - & RRI, MS \\
\hline 89 & 1804 & Myrtenol & 0.2 & - & 0.2 & - & - & - & - & 1.7 & - & - & 0.4 & MS \\
\hline 90 & 1807 & Fragranol & - & - & - & - & - & 2.2 & - & - & - & - & - & MS \\
\hline 91 & 1808 & Nerol & - & - & - & - & - & 0.6 & - & - & - & - & - & RRI, MS \\
\hline 92 & 1823 & $p$-Mentha-1(7),5-dien-2-ol & - & - & - & - & - & - & 0.1 & - & - & - & - & MS \\
\hline 93 & 1830 & Tridecanal & - & - & - & - & 0.1 & - & 0.2 & - & - & - & - & MS \\
\hline
\end{tabular}


Table 1. Cont.

\begin{tabular}{|c|c|c|c|c|c|c|c|c|c|c|c|c|c|c|}
\hline \multirow{2}{*}{ No } & \multirow{2}{*}{$\mathbf{R R I}^{\mathbf{a}}$} & \multirow{2}{*}{ Compound } & \multicolumn{11}{|c|}{ Content ${ }^{\mathrm{b}} \%$} & \multirow{2}{*}{$\mathrm{IM}^{\mathrm{c}}$} \\
\hline & & & $\mathbf{A B}$ & $\mathbf{A C}$ & $\mathbf{A H}$ & $\mathbf{A K}$ & $\mathbf{A L}$ & AM & ASc & ASe & $\mathbf{A S i}$ & AV & AW & \\
\hline 94 & 1849 & Calamenene & - & - & - & - & - & 0.2 & - & - & - & - & - & MS \\
\hline 95 & 1857 & Geraniol & - & - & - & - & - & - & 0.2 & - & - & - & - & RRI, MS \\
\hline 96 & 1868 & (E)-Geranyl acetone & - & - & - & - & 0.2 & - & 0.1 & - & - & 0.1 & - & MS \\
\hline 97 & 1898 & 1,11-Oxidocalamenene & - & - & - & - & - & 0.5 & - & - & - & - & - & MS \\
\hline 98 & 1900 & epi-Cubebol & - & - & - & - & & - & $\operatorname{tr}$ & - & - & - & - & MS \\
\hline 99 & 1900 & Nonadecane & - & - & - & - & - & - & - & - & - & 0.1 & - & RRI, MS \\
\hline 100 & 1921 & $\alpha$-Phellandrene epoxide & - & - & - & - & - & - & 0.3 & - & - & - & - & MS \\
\hline 101 & 1941 & $\alpha$-Calacorene & - & - & - & - & - & 1.1 & 0.1 & - & - & - & - & MS \\
\hline 102 & 1945 & 1,5-Epoxy-salvial(4)14-ene & - & - & - & - & 3.9 & - & - & - & 0.4 & 1.1 & - & MS \\
\hline 103 & 1953 & Palustrol & - & 0.8 & - & - & - & - & - & - & - & - & - & MS \\
\hline 104 & 1957 & Cubebol & - & - & - & - & 0.3 & - & 0.1 & - & - & - & - & MS \\
\hline 105 & 1958 & (E)- $\beta$-Ionone & - & - & - & - & - & - & - & - & - & 0.6 & - & MS \\
\hline 106 & 1969 & cis-Jasmone & 0.5 & - & - & - & 0.3 & - & - & - & - & - & - & MS \\
\hline 107 & 1984 & $\gamma$-Calacorene & - & - & - & - & - & 0.2 & - & - & - & - & - & MS \\
\hline 108 & 2001 & Isocaryophyllene oxide & - & - & 0.2 & - & - & - & 0.3 & - & - & - & - & MS \\
\hline 109 & 2008 & Caryophyllene oxide & 0.4 & 9.6 & 3.9 & 10.1 & 3.2 & 7.7 & 17.5 & 3.1 & 7.5 & 0.7 & 3.1 & RRI, MS \\
\hline 110 & 2030 & Methyl eugenol & - & - & - & - & - & - & - & - & - & 0.1 & - & RRI, MS \\
\hline 111 & 2037 & Salvial-4(14)-en-1-one & - & - & - & - & 1.7 & - & 0.2 & - & 0.6 & 0.4 & - & MS \\
\hline 112 & 2041 & Pentadecanal & 0.2 & - & 0.2 & - & 1.0 & 0.3 & - & 0.5 & 0.7 & 0.7 & 0.2 & MS \\
\hline 113 & 2050 & (E)-Nerolidol & - & - & 2.2 & 1.6 & - & 1.1 & 6.2 & - & 0.4 & 4.4 & - & MS \\
\hline 114 & 2056 & 13-Tetradecanolide & 0.2 & - & - & - & 0.7 & - & - & 0.8 & - & - & 1.5 & MS \\
\hline 115 & 2057 & Ledol & - & 1.6 & - & - & - & 0.5 & 0.7 & - & - & - & - & MS \\
\hline 116 & 2071 & Humulene epoxide-II & - & 0.4 & - & 0.5 & 0.5 & 0.8 & 1.1 & - & 0.3 & - & - & MS \\
\hline 117 & 2074 & Caryophylla-2(12),6(13)-dien-5-one & - & 0.8 & - & 0.9 & 0.2 & - & 0.5 & - & 0.6 & - & 1.8 & MS \\
\hline
\end{tabular}


Table 1. Cont.

\begin{tabular}{|c|c|c|c|c|c|c|c|c|c|c|c|c|c|c|}
\hline \multirow{2}{*}{ No } & \multirow{2}{*}{$\mathbf{R R I}^{\mathrm{a}}$} & \multirow{2}{*}{ Compound } & \multicolumn{11}{|c|}{ Content ${ }^{\text {b } \%}$} & \multirow{2}{*}{$\mathbf{I M}^{\mathrm{c}}$} \\
\hline & & & $\mathbf{A B}$ & $\mathbf{A C}$ & $\mathbf{A H}$ & AK & $\mathbf{A L}$ & AM & ASc & ASe & $\mathbf{A S i}$ & $\mathbf{A V}$ & AW & \\
\hline 118 & 2080 & Junenol (=Eudesm-4(15)-en-6-ol) & - & - & - & - & - & - & 0.2 & - & - & - & - & MS \\
\hline 119 & 2088 & 1-epi-Cubenol & - & - & - & - & - & 4.1 & - & - & - & - & - & MS \\
\hline 120 & 2092 & $\beta$-Oplopenone & - & - & - & - & 0.5 & - & - & - & - & - & - & MS \\
\hline 121 & 2104 & Viridiflorol & - & 25.9 & - & 3.9 & - & - & 0.2 & - & - & - & - & MS \\
\hline 122 & 2130 & Salviadienol & - & - & - & - & 0.8 & - & - & - & - & - & - & MS \\
\hline 123 & 2131 & Hexahydrofarnesyl acetone & 0.3 & - & - & 0.8 & 3.3 & 0.2 & 0.6 & 0.8 & 0.7 & 1.1 & 0.6 & MS \\
\hline 124 & 2144 & Spathulenol & 0.5 & 1.3 & 2.0 & 2.6 & 4.6 & 2.5 & 9.1 & 2.2 & 2.7 & 3.3 & 0.4 & MS \\
\hline 125 & 2156 & $\alpha$-Bisabolol oxide B & - & - & - & - & - & 0.7 & - & 5.7 & - & - & - & MS \\
\hline 126 & 2161 & Bisabolol oxide & - & - & - & - & - & 0.6 & - & 1.1 & - & - & - & RRI, MS \\
\hline 127 & 2161 & Muurola-4,10(14)-dien-1-ol & - & - & - & - & - & 6.8 & 0.2 & - & - & - & - & MS \\
\hline 128 & 2179 & 1-Tetradecanol & - & - & - & - & 0.4 & - & 0.1 & - & - & 0.7 & - & MS \\
\hline 129 & 2185 & $\gamma$-Eudesmol & 0.1 & - & - & - & - & - & - & - & - & - & - & MS \\
\hline 130 & 2186 & Eugenol & 0.1 & - & - & - & - & - & - & - & - & - & - & RRI, MS \\
\hline 131 & 2187 & T-Cadinol & - & - & 0.4 & 1.0 & 1.1 & - & 1.2 & - & - & - & 0.6 & MS \\
\hline 132 & 2191 & Zingiberenol & - & - & - & - & - & - & - & 0.4 & - & - & - & MS \\
\hline 133 & 2198 & Thymol & 0.5 & - & - & 0.6 & - & - & 1.2 & - & - & - & 2.1 & RRI, MS \\
\hline 134 & 2200 & $\alpha$-Bisabolon oxide A & - & - & - & - & - & - & - & 27.0 & - & - & - & MS \\
\hline 135 & 2204 & Eremoligenol & - & - & - & - & - & - & 0.8 & - & - & - & - & MS \\
\hline 136 & 2209 & T-Muurolol & - & - & 0.3 & - & - & - & - & - & - & 0.2 & - & MS \\
\hline 137 & 2210 & Copaborneol & - & - & - & - & 0.8 & - & - & - & - & - & - & MS \\
\hline 138 & 2211 & Clovenol & - & 0.6 & - & - & - & - & 0.3 & - & - & - & - & MS \\
\hline 139 & 2214 & $a r$-Turmerol & - & - & - & - & 0.5 & - & - & 0.6 & - & 0.8 & - & MS \\
\hline 140 & 2221 & Isocarvacrol & 0.4 & - & - & - & - & - & - & - & - & - & - & MS \\
\hline 141 & 2232 & $\alpha$-Bisabolol & - & - & - & - & - & 11.7 & - & 4.8 & - & 0.5 & - & RRI, MS \\
\hline
\end{tabular}


Table 1. Cont.

\begin{tabular}{|c|c|c|c|c|c|c|c|c|c|c|c|c|c|c|}
\hline \multirow{2}{*}{ No } & \multirow{2}{*}{ RRI $^{a}$} & \multirow{2}{*}{ Compound } & \multicolumn{11}{|c|}{ Content ${ }^{\mathrm{b}} \%$} & \multirow{2}{*}{$\operatorname{IM}^{\mathrm{c}}$} \\
\hline & & & $\mathbf{A B}$ & $\mathbf{A C}$ & $\mathbf{A H}$ & $\mathbf{A K}$ & $\mathbf{A L}$ & AM & ASc & ASe & $\mathbf{A S i}$ & AV & AW & \\
\hline 142 & 2239 & Carvacrol & 1.4 & - & - & - & - & - & 0.6 & - & - & - & 0.3 & RRI, MS \\
\hline 143 & 2241 & Heptadecanal & - & - & - & - & 0.9 & - & - & - & - & - & - & MS \\
\hline 144 & 2247 & trans- $\alpha$-Bergamotol & - & - & - & - & - & - & 0.4 & - & - & - & - & MS \\
\hline 145 & 2255 & $\alpha$-Cadinol & - & - & - & 0.3 & - & - & - & - & - & - & - & RRI, MS \\
\hline 146 & 2256 & Cadalene & - & - & - & - & - & 1.4 & - & - & - & - & - & MS \\
\hline 147 & 2257 & $\beta$-Eudesmol & 10.1 & 7.4 & 1.9 & 4.9 & - & - & 3.4 & - & 26.4 & 4.4 & - & RRI, MS \\
\hline 148 & 2260 & 15-Hexadecanolide & 0.6 & 9.4 & - & - & 2.2 & - & - & - & - & 19.6 & 0.9 & MS \\
\hline 149 & 2264 & Intermedeol & - & - & - & 0.7 & - & - & - & - & - & - & - & MS \\
\hline 150 & 2279 & Pentadecanol & - & - & - & - & - & - & - & 0.7 & - & - & - & MS \\
\hline 151 & 2300 & Tricosane & 0.9 & 0.8 & - & 0.7 & 1.3 & 0.4 & 0.7 & 1.2 & 2.4 & 1.4 & 0.4 & RRI, MS \\
\hline 152 & 2316 & $\begin{array}{c}\text { Caryophylla-2(12),6(13)-dien-5 } 3 \text {-ol } \\
(=\text { Caryophylladienol I) }\end{array}$ & - & 0.9 & 1.0 & 0.6 & 0.1 & 0.8 & 1.5 & - & 1.6 & - & 2.3 & MS \\
\hline 153 & 2324 & $\begin{array}{c}\text { Caryophylla-2(12),6(13)-dien-5 } \alpha \text {-ol } \\
(=\text { Caryophylladienol II })\end{array}$ & - & 4.3 & 2.9 & 2.4 & 2.7 & 2.6 & 4.9 & 1.2 & 4.8 & - & 6.4 & MS \\
\hline 154 & 2325 & Bisabolone & - & - & - & - & - & - & - & 0.7 & - & - & - & RRI, MS \\
\hline 155 & 2369 & Eudesma-4(15),7-dien-4 $\beta$-ol & - & - & - & - & 0.6 & 0.6 & 0.9 & - & 0.6 & 1.0 & - & MS \\
\hline 156 & 2384 & Hexadecanol & - & - & - & - & - & - & - & 0.5 & - & 0.6 & - & MS \\
\hline 157 & 2389 & $\begin{array}{l}\text { Caryophylla-2(12),6-dien-5 } \alpha \text {-ol } \\
\quad=\text { Caryophyllenol })\end{array}$ & - & 2.9 & - & 1.1 & 1.1 & - & 1.2 & - & 0.5 & - & 0.7 & MS \\
\hline 158 & 2392 & 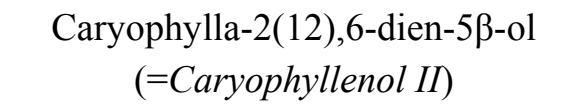 & - & 2.9 & 1.0 & 1.7 & 1.5 & 1.2 & 3.8 & - & 2.4 & - & 2.7 & MS \\
\hline 159 & 2400 & Tetracosane & - & - & - & - & - & - & - & - & 0.5 & 0.8 & - & RRI, MS \\
\hline 160 & 2411 & 4-Isopropyl-6-methyl-1-tetralone & - & - & - & - & - & 0.6 & - & - & - & - & - & MS \\
\hline 161 & 2430 & Chamazulene & - & - & - & - & - & 0.4 & - & - & - & - & - & MS \\
\hline
\end{tabular}


Table 1. Cont.

\begin{tabular}{|c|c|c|c|c|c|c|c|c|c|c|c|c|c|c|}
\hline \multirow{2}{*}{ No } & \multirow{2}{*}{ RRI $^{a}$} & \multirow{2}{*}{ Compound } & \multicolumn{11}{|c|}{ Content $\mathrm{b} \%$} & \multirow{2}{*}{$\mathbf{I M}^{\mathrm{c}}$} \\
\hline & & & $\mathbf{A B}$ & $\mathrm{AC}$ & $\mathbf{A H}$ & $\mathbf{A K}$ & $\mathbf{A L}$ & AM & ASc & ASe & $\mathbf{A S i}$ & $\mathbf{A V}$ & $\mathbf{A W}$ & \\
\hline 162 & 2438 & $\alpha$-Bisabolol oxide $\mathrm{A}$ & - & - & - & - & - & - & - & 0.7 & - & - & - & MS \\
\hline 163 & 2475 & 1-Heptadecanol & - & - & - & - & - & - & - & - & - & 1.0 & - & MS \\
\hline 164 & 2500 & Pentacosane & 1.4 & 0.7 & - & 1.2 & 6.1 & 1.5 & 0.2 & 2.2 & 3.7 & 4.4 & 1.3 & RRI, MS \\
\hline 165 & 2607 & 1-Octadecanol & - & 0.8 & - & - & 1.0 & - & - & - & 2.2 & 2.0 & 0.6 & MS \\
\hline 166 & 2607 & Octadecanol & - & - & - & 0.5 & - & - & - & - & - & - & - & MS \\
\hline 167 & 2622 & Phytol & - & - & - & - & 1.0 & 0.4 & - & - & - & 0.9 & - & MS \\
\hline 168 & 2670 & Tetradecanoic acid & 0.8 & - & - & 0.7 & - & - & - & - & 1.4 & - & - & RRI, MS \\
\hline 169 & 2676 & (Z)-Octadec-9-en-18-olide & 0.3 & - & - & - & 1.3 & - & - & - & - & - & - & MS \\
\hline 170 & 2679 & Manool & - & - & - & - & - & - & - & - & - & 0.3 & - & MS \\
\hline 171 & 2700 & Heptacosane & 1.0 & - & - & 1.7 & 9.2 & 1.8 & 0.7 & 1.6 & 4.1 & 6.3 & 1.1 & RRI, MS \\
\hline 172 & 2795 & Eicosanol & - & - & - & - & - & - & - & - & 1.7 & - & - & MS \\
\hline 173 & 2800 & Octacosane & - & - & - & - & - & - & - & - & 1.3 & - & - & RRI, MS \\
\hline 174 & 2822 & Pentadecanoic acid & 0.4 & - & - & - & - & - & - & - & - & - & - & RRI, MS \\
\hline 175 & 2900 & Nonacosane & 0.2 & - & - & $\operatorname{tr}$ & 10.6 & 2.6 & 0.4 & 1.3 & 2.6 & 4.1 & 1.1 & RRI, MS \\
\hline \multirow[t]{10}{*}{176} & 2931 & Hexadecanoic acid & 11.2 & 8.2 & - & 7.7 & - & 4.6 & 1.9 & 16.4 & 22.7 & - & 0.6 & RRI, MS \\
\hline & & Monoterpene Hydrocarbones & 39.5 & 3.5 & 32.7 & 36.8 & 0.2 & 6.6 & 13.3 & 3.1 & 0.6 & - & 13.3 & \\
\hline & & Oxygenated Monoterpenes & 26.6 & 13.8 & 32.5 & 10.5 & 11 & 18.9 & 9.8 & 8.8 & 2.1 & 26.8 & 56.4 & \\
\hline & & Sesquiterpene Hydrocarbones & 0.1 & 0.7 & 11.5 & 0.4 & 0.5 & 4.3 & 6.4 & 1.2 & 0.3 & 1.6 & 0.7 & \\
\hline & & Oxygenated Sesquiterpenes & 11.1 & 59.4 & 15.8 & 32.3 & 24.1 & 42.2 & 55.4 & 47.5 & 48.8 & 16.8 & 18 & \\
\hline & & Diterpenes & - & - & - & - & 1.0 & 0.4 & & - & - & 1.2 & - & \\
\hline & & Fatty acid + esters & 12.4 & 8.2 & - & 8.4 & - & 4.6 & 1.9 & 16.4 & 24.1 & - & 0.6 & \\
\hline & & Others & 6.0 & 11.7 & 0.5 & 4.9 & 39.3 & 7.8 & 3.1 & 9.6 & 19.9 & 43.9 & 8.8 & \\
\hline & & Identified components & 55 & 28 & 45 & 41 & 48 & 57 & 82 & 31 & 30 & 46 & 46 & \\
\hline & & Total & 95.7 & 97.3 & 93.0 & 93.3 & 76.1 & 84.8 & 89.9 & 86.6 & 95.8 & 90.3 & 97.8 & \\
\hline
\end{tabular}

${ }^{a}$ Relative retention indices calculated against $n$-alkanes; ${ }^{\mathrm{b}} \%$ calculated from TIC data. ${ }^{\mathrm{c}}$ IM: Identification method based on the relative retention indices (RRI) of authentic compounds on the HP Innowax column; MS, identified on the basis of computer matching of the mass spectra with those of the Wiley and MassFinder libraries and comparison with literature data; tr: $<0.1 \%$. 
The main components of $A$. kotschyi subsp. kotschyi oil were determined as 1,8-cineole (22.5\%), caryophyllene oxide (10.1\%), p-cymene (8.4\%) and hexadecanoic acid (7.7\%). Forty-one components were identified representing $93.3 \%$ of the total A. kotschyi subsp. kotschyi essential oil. Although A. kotschyi subsp. kotschyi is distributed in Turkey, Bulgaria and Lebanon [2], the literature for the chemical constituents of its essential oil is poor. There is only one report on the essential oil composition of A. kotschyi subsp. kotschyi. According to this report, 22 components were characterized, of which 1,8-cineole and caryophyllene oxide were reported as major components [21]. Other major volatile compounds, such as $p$-cymene and hexadecanoic acid, were identified and reported in the present study for the first time.

Nonacosane (10.6\%), heptacosane $(9.2 \%)$ and pentacosane $(6.1 \%)$ were main constituents of the oil of $A$. lycaonica. Forty-eight components were characterized representing $76.1 \%$ of the total oil. Previous data on $A$. lycaonica essential oil is very limited. Thirteen compounds were identified in A. lycaonica essential oil and L-camphor, artemisia alcohol and camphor, were reported as major components of the oil [22]. In another study, trans-sabinene hydrate, terpinen-4-ol and caryophyllene oxide were reported to be main constituent of A. lycaonica essential oil [23].

A total of 57 compounds were characterized in A. millefolium subsp. millefolium essential oil, representing $84.8 \%$ of the total oil. This oil which was characterized by a high content of $\alpha$-bisabolol (11.7\%), caryophyllene oxide (7.7\%) and muurola-4,10(14)-dien-1-ol (6.8\%) was dominated by oxygenated sesquiterpenes. A. millefolium subsp. millefolium, which is an officinal species, is registered in many pharmacopoeias and monograph books. Therefore numerous papers describing the chemical composition of essential oil of $A$. millefolium subsp. millefolium from different regions of the world have been written. The major components were reported in different locations as follows: D-cadinene, limonene oxide, alloaromadendrene, caryophyllene oxide, trans-caryophyllene [24] and 1,8-cineol, camphor, $\alpha$-terpineol, $\beta$-pinene, borneol [25] in Turkey; $\alpha$-asarone, $\beta$-bisabolene, $\alpha$-pinene [26] and 1,8-cineole, sabinene, $\alpha$-terpineol, terpinen-4-ol, $\gamma$-eudesmol, $6 S, 7 R$-bisabolone [27] in Italy; trans-thujone, trans-chrysanthenyl acetate, $\beta$-pinene in Portuguese [26], 1,8-cineole, bornyl acetate, $\gamma$-terpinene, terpinolene in Macedonia [28]; 1,8-cineole, camphor in Serbia [29], $\beta$-pinene, sabinene, 1,8-cineole, $\beta$-caryophyllene, $(E)$-nerolidol, guaiol, chamazulene in Estonia [30]; borneol, camphor; chamazulene, $\beta$-pinene; trans-nerolidol, $\beta$-pinene and $\beta$-pinene, 1,8-cineole in Lithuania [31]; 1,8-cineole [32] and 1,8-cineole, germacrene D in Iran [33], camphor in Kazakhstan [34]; camphor, 1,8-cineole, germacrene D, cis-chrysanthenyl acetate in India [35]; and $\beta$-pinene, 1,8-cineole, borneol, $\beta$-caryophyllene in Mt. Himalaya (India) [36].

The main components of $A$. schischkinii oil were determined as caryophyllene oxide (17.5\%), spathulenol $(9.1 \%), p$-cymene $(8.5 \%)$ and $(E)$-Nerolidol (6.2\%). Eighty-two components were identified, representing $89.9 \%$ of the total $A$. schischkinii essential oil. Donmez et al., previously reported 31 components, in the essential of $A$. schischkinii [37]. In this study, 1,8-cineole and camphor were found to be major compounds while caryophyllene oxide, spathulenol and nerolidol (correct isomer was not identified) were reported in small quantities $(0.2 \%-1.1 \%)$. On the other hand, $p$-cymene was not identified in A. schischkinii. According to Iscan et al. [38], 44 components were characterized, and of which 1,8-cineole was identified as the main constituent while caryophyllene oxide, spathulenol and $p$-cymene were reported in lesser quantity (less than $0.1 \%$ ). (E)-Nerolidol was not identified and reported in mentioned study. 
In the oil of $A$. setacea, a sum of 31 components were characterized representing $86.6 \%$ of the total oil, with $\alpha$-bisabolon oxide A $(27.0 \%)$ and hexadecanoic acid (16.4\%) as the main constituents. 1,8-cineole and sabinene were previously reported as major components in A. setacea [39]. Noteworthy, $\alpha$-bisabolon oxide A and hexadecanoic acid were not reported either in major or minor quantities previously.

$\beta$-eudesmol (26.4\%), hexadecanoic acid (22.7\%) and caryophyllene oxide (7.5\%) were main constituents of the oil of $A$. sintenisii. Thirty components were characterized representing $95.8 \%$ of the total oil. A literature survey revealed that there is only one report on the essential oil composition of A. sintenisii [40]. According to this study, camphor, 1,8-cineole, $\beta$-pinene, borneol and piperitone were reported as main constituents. Minor quantities of caryophyllene oxide were also reported in this study. Our results showed that $\beta$-eudesmol and hexadecanoic acid were reported for the first time in A. sintenisii essential oil.

A total of 46 compounds were characterized in A. vermicularis essential oil, representing $90.3 \%$ of the total oil with 15 -hexadecanolide (19.6\%), camphor $(6.7 \%)$, heptacosane $(6.3 \%)$ and bornyl acetate (5.1\%). 1,8-cineole and camphor were previously reported as main components in A. vermicularis from Iran and Turkey [18,41], whereas, in our study, 1,8-cineole was not detected and identified in the essential oil of these species.

In the oil of the A. wilhelmsii subsp. Wilhelmsii, 46 components were characterized representing $97.8 \%$ of the total oil. Camphor (41.3\%), caryophylladienol II (6.4\%), borneol $(6.2 \%)$ and camphene $(6.1 \%)$ were found as the other main constituents. There are several different reports on the essential oil composition of $A$. wilhelmsii subsp. wilhelmsii from Egypt and different locations of Iran. According to the report on A. wilhelmsii growing in Egypt, the major component of essential oil was 1,8-cineole, while camphor, 1,8-cineole, $\alpha$-pinene; camphor, 1,8 cineole, $\alpha$-pinene; caryophyllene oxide, camphor, borneol; carvacrol, linalool, 1,8-cineole; camphor, borneol and 1,8-cineole were the major identified compounds in this plant essential oil collected from Iran [42-46]. On the other hand, camphor was previously reported to be main component in the oil of Achillea wilhelmsii from Turkey [22].

In addition to these findings, we have investigated essential oil composition of A. hamzaoglui, and evaluated antioxidant and antimicrobial activities of both essential oil and methanol extract of the plant. This is the first report on chemical composition of A. hamzaoglui essential oil and data is given in Table 1. Forty-five components were identified representing $93 \%$ of the total $A$. hamzaoglui essential oil. The main components were determined as 1,8 -cineole $(24.1 \%)$, linalool $(12.2 \%)$ camphor $(6.7 \%)$ and germacrene $\mathrm{D}(6.2 \%)$.

\subsection{Principal Components Analysis (PCA) and Hierarchical Cluster Analysis (HCA)}

Thirty compounds were included in the PCA and HCA analysis with average concentrations ranging between $0.6 \%-8.25 \%$. The PCA analysis showed that the first two factorial plans retained, $24.8 \%$ and $17.1 \%$ of total variance in the data, respectively (Figure 1). 


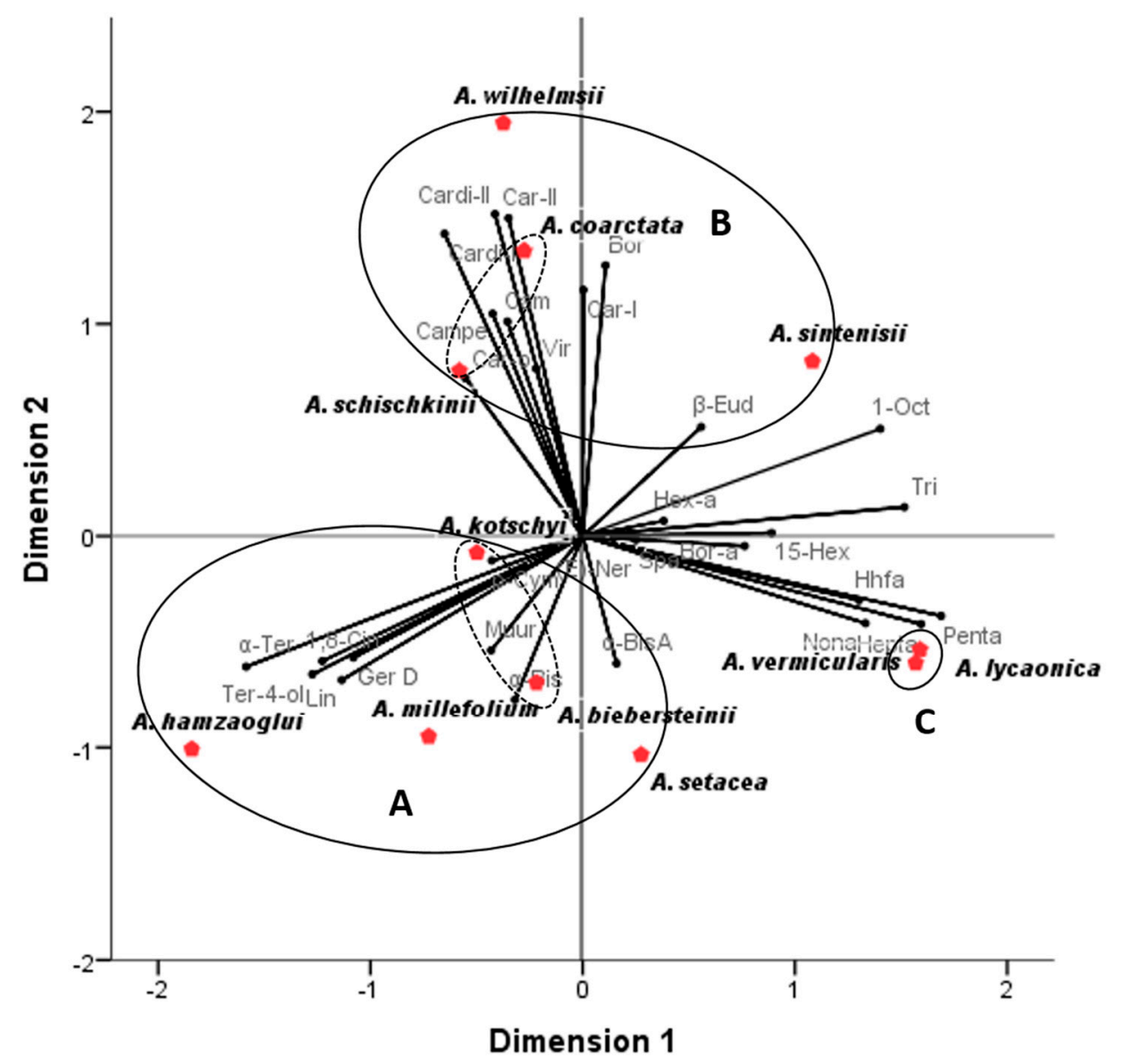

Figure 1. PCA biplot of major volatile compounds of eleven Achillea species according to the clusters $(\mathbf{A}-\mathbf{C})$ they belong to. Axes refer to scores for the samples and loadings from the volatile constituents represented as vectors from the origin. 1-Oct: 1-Octadecanol; 1,8Cin: 1,8-Cineole; 15-Hex: 15-Hexadecanolide; $\alpha$-BisA: $\alpha$-Bisabolon oxide A; $\alpha$-Bis: $\alpha$ Bisabolol; $\alpha$-Ter: $\alpha$-Terpineol; $\beta$-Eud: $\beta$-Eudesmol; $p$-Cym: $p$-Cymene; Bor: Borneol; Bora: Bornyl acetate; Campe: Camphene, Cam: Camphor; Car-I: Caryophylla-2(12),6-dien-5 $\alpha-$

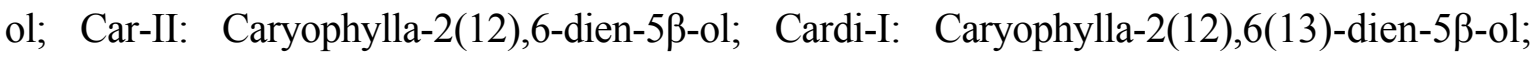
Cardi-II: Caryophylla-2(12),6(13)-dien-5 $\alpha$-ol; Car-o: Caryophyllene oxide; $(E)$-Ner: $(E)$ Nerolidol; Ger D: Germacrene D; Hepta: Heptacosane; Hex-a: Hexadecanoicacid; Hhfa: Hexahydrofarnesyl acetone; Lin: Linalool; Muur: Muurola-4,10(14)-dien-1-ol; Nona: Nonacosane; Penta: Pentacosane; Spa: Spathulenol; Ter-4-ol: Terpinen-4-ol; Tri: Tricosane; and Vir: Viridiflorol.

HCA based on the Euclidean distance between groups indicated a solution with three clusters. The number of clusters (A, B and C, Figure 2) were determined by using the rescaled distances in the dendrogram, using a cut-off point where the distances among clusters that are combined increase substantially, indicating the treshold where combining more clusters would increase within-group variability excessively in terms of volatile composition. These clusters formed separate groups in the PCA biplot (Figure 1). The horizontal axis correlated positively with cluster C. The vertical axis correlated positively with cluster B and negatively with cluster A. Essential oils with an average of more than $5 \%$ concentration were 1,8 -cineol $(14.1 \%)$, hexadecanoicacid $(8.0 \%)$, camphor $(5.9 \%)$, $p$-cymene 
(5.7\%), $\alpha$-bisabolon oxide A (5.4\%), and caryophyllene oxide (5.0\%) for cluster A; camphor (13.3\%), caryophyllene oxide $(9.4 \%)$, $\beta$-Eudesmol $(9.3 \%)$, hexadecanoicacid $(8.4 \%)$, viridiflorol $(6.5 \%)$, and caryophylla-2(12),6(13)-dien-5 $\alpha$-ol (5.1\%) for cluster B; and 15-hexadecanolide (10.9\%), heptacosane (7.8\%), nonacosane $(7.4 \%)$, and pentacosane $(5.3 \%)$ for cluster $\mathrm{C}$.

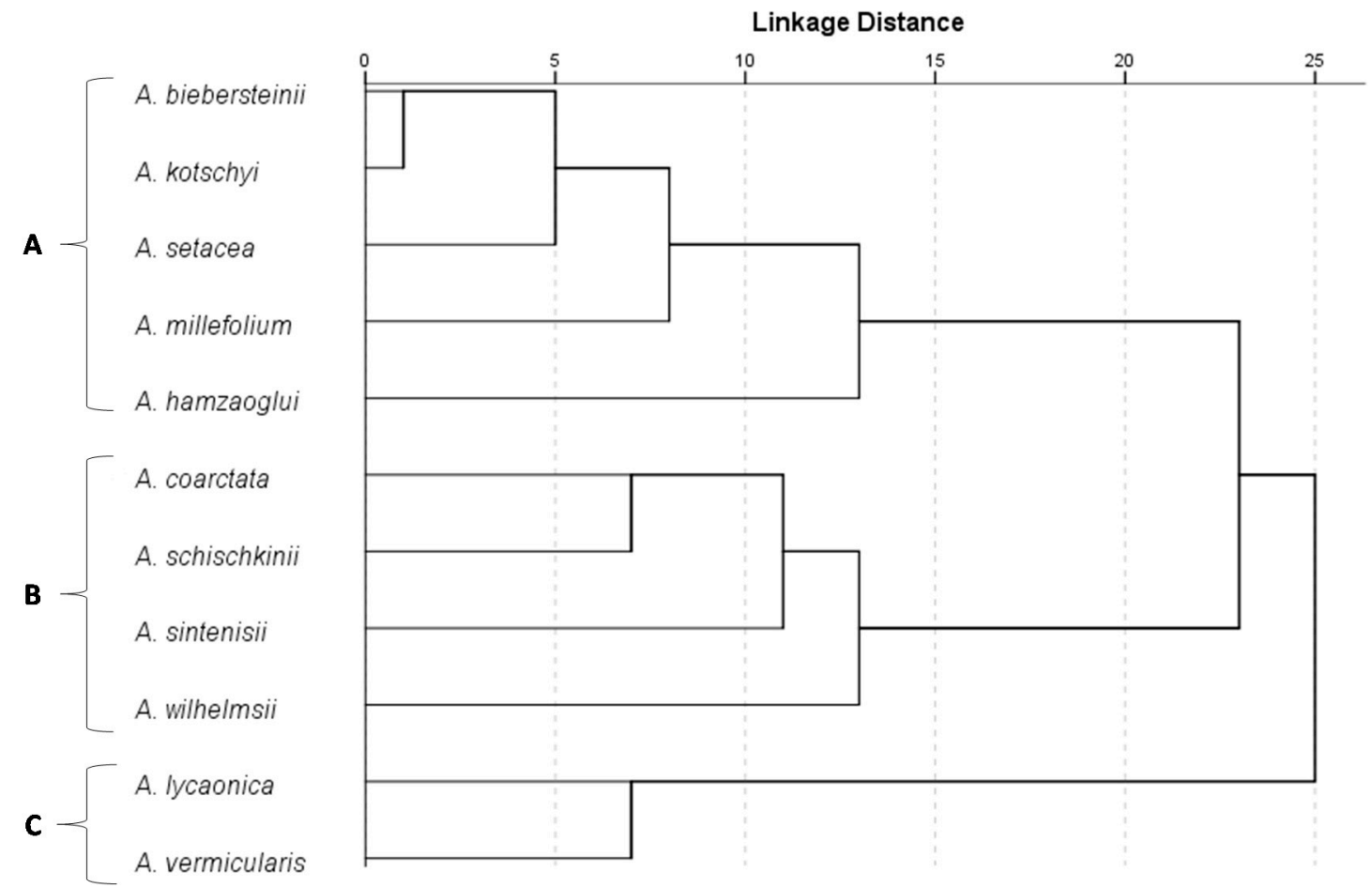

Figure 2. Dendrogram obtained by HCA based on the Euclidean distance between groups of the essential oils of eleven Achillea species growing in Turkey. A. setacea essential oil was characterized by the highest percentages of two main components in group A: $\alpha$-bisabolon oxide $\mathrm{A}$ and hexadecanoic acid (27\% and $16.4 \%$, respectively) and a moderate content of $\alpha$-bisabolol (4.8\%). The essential oil of $A$. millefolium subsp. millefolium essential oil was characterized by the highest percentages of $\alpha$-bisabolol and muurola-4,10(14)-dien-1-ol (11.7\% and $6.8 \%$, respectively) as well as its caryophyllene oxide and hexadecanoic acid content (7.7\% and $4.6 \%$, respectively) while $A$. hamzaoglui essential oil was characterized by the highest levels of 1,8-cineol, linalool, germacrene D $(24.1 \%, 12.2 \%$ and $6.2 \%$, respectively) in group A.

Group A species comprised A. biebersteinii, A. kotschyi subsp. kotschyi, A. setacea, A. millefolium subsp. millefolium and A. hamzaoglui. According to PCA analysis, A. biebersteinii and A. kotschyi subsp. kotschyi, forms a subgroup in group A, because of their high contents of 1,8-cineole $(16.5 \%$ and $22.5 \%$, respectively), $p$-cymene ( $18.6 \%$ and $8.4 \%$, respectively), hexadecanoic acid $(11.2 \%$ and $7.7 \%$, respectively) and relatively moderate contents of $\beta$-eudesmol (10.1\% and $4.9 \%$, respectively). One of the main variations between the subgroup and three other species was due to bornyl acetate content of A. biebersteinii and A. kotschyi subsp. kotschyi ( $0.2 \%$ and $1.3 \%$, respectively) against $0 \%$ for the three other species. The A. biebersteinii essential oil was richer in camphor (11.7\%), whereas A. kotschyi subsp. kotschyi oil was richer in caryophyllene oxide (10.1\%) and viridiflorol (3.9\%). 
Group B was represented by A. coarctata, A. schischkinii, A. sintenisii and A. wilhelmsii subsp. wilhelmsii. A. coarctata essential oil was characterized by the highest percentages of viridiflorol and 15 -hexadecanolide (25.9\% and 9.4\%, respectively) in group B. It also contains relatively higher amounts of camphor, caryophyllene oxide, hexadecanoic acid and $\beta$-eudesmol $(9.8 \%, 9.6 \%, 8.2 \%$ and 7.4\%, respectively). A. schischkinii essential oil was the richest oil in terms of caryophyllene oxide, spathulenol and $(E)$-nerolidol contents $(17.5 \%, 9.2 \%$ and $6.2 \%$, respectively), whereas $A$. sintenisii essential oil was the richest one in terms of $\beta$-eudesmol and hexadecanoic acid (26.4\% and $22.7 \%$, respectively). A. sintenisii essential oil also contains relatively moderate percentage of caryophyllene oxide (7.5\%). In Group B, A. wilhelmsii subsp. wilhelmsii was characterized by the highest percentages of camphor, caryophylla-2(12),6(13)-dien-5 $\alpha$-ol, borneol and camphene (41.3\%, 6.4\%, 6.2\% and 6.1\%, respectively).

Group C, represented by A. lycaonica and A. vermicularis. A. lycaonica was characterized by higher percentages of nonacosane, heptacosane and pentacosane $(10.6 \%, 9.2 \%$ and $6.1 \%$, respectively) while A. vermicularis essential oil was characterized by the highest percentage of 15-hexadecanolide (19.6\%). A.vermicularis was also richer in terms of camphor, bornyl acetate and $(E)$-nerolidol content $(6.7 \%$, $5.1 \%$ and $4.4 \%$, respectively).

In the genus Achilea, composition of the essential oil is highly variable due to some biotic and abiotic factors, such as ontogenic and morphogenic differentiations, environmental factors and applied method of oil extraction [47]. Previous studies on the oil composition of Achillea species revealed that 1,8-cineole was the most abundant compound, ranging from trace levels to $47.7 \%$ in essential oils of Balkan Achillea, while camphor and borneol were the second and third repeatedly detected compounds, respectively. Moreover, caryophyllene oxide and $\beta$-caryophyllene were reported to be frequently identified sesquiterpenoids [5,15,16]. According to our results, all Achillea species, except A. vermicularis, investigated in this study contain 1,8 -cineole from $0.2 \%$ to $24.1 \%$. Contrary to Balkan Achillea, camphor, which was detected in all species between $0.5 \%$ and $41.3 \%$, was found to be the most abundant compound in this study. In addition to camphor, caryophyllene oxide and spathulenol were detected in all species. 1,8-cineole, borneol, tricosane and pentacosane were the second most detected compounds (Table 1). Oxygenated sesquiterpenes such as $\beta$-eudesmol, viridiflorol, spathulenol, nerolidol, caryophyllene oxide, caryophylladienol II, $\alpha$-bisabolon oxide, $\alpha$-bisabolol and muurola-4,10(14)-dien-1-ol were found to be major components of investigated species. Among sesquiterpenes, chamazulene was regarded as characteristics of the members of Millefolium group (Syn: sect. Achillea) by Radulovic et al. [16]. However, according to some other researchers, this is not accepted as a universal phenomenon in the group because some species belonging Millefolium group was reported most of the cases as chamazulene free, moreover, some species outside the group contain chamazulene [15,47]. In paralel to this agreement, in the present study, among five species belonging Millefolium group, A. biebersteinii, A. coarctata, A. kotschyi subsp. kotschyi, A. millefolium subsp. millefolium and A. setacea, chamazulene was detected only in A. millefolium subsp. millefolium ( $0.4 \%)$. Futhermore, chamazulene was reported as one of the major components of essential oil of A. millefolium subsp. millefolium [30,31], while in many cases, the species was chamazulene free [24,25,32]. Cubebene, which was reported previously from Achillea species [15], was not identified in this study. Besides sesquiterpenes, in this study, some fatty acid derived compounds such as 15-hexadecanolide, hexadecanoic acid, nonacosane, heptacosane and pentacosane were found to be as major compounds in nine species (in minor quantities in A. schischkinii and A. millefolium subsp. millefolium) (Table 1). 
Noteworthy, major compounds of A. lycaonica investigated in this study were consists of fatty acid derived compounds.

\subsection{Antioxidant and Antimicrobial Activity of Essential Oil and Methanol Extract of A. hamzaoglui}

Free radicals, which are continuously produced in human body as normal products of cellular metabolism, are essential for several physiological processes in low concentrations. However, in higher amounts they can react with membrane lipids, nucleic acids, proteins, enzymes and other small molecules and cause human diseases, including cancer, diabetes, atherosclerosis, failures in immunity and endocrine functions [48]. Antioxidants act as safeguard against the accumulation of free radicals and their elimination from the system. In addition, due to their important role in living systems, antioxidants have been widely used in cosmetics and foods [49]. In the present study, free radical scavenging activity of characterized essential oil (AH-EO) and methanolic extract (AH-ME) of A. hamzaoglui was evaluated by DPPH method in comparison with that of a synthetic antioxidant, tert-butylhydoxy-toluene (BHT), at different concentrations [50]. Radical scavenger activity was expressed as the amount of antioxidants necessary to decrease the initial DPPH absorbance by $50 \%$ (median effective concentration value, $\mathrm{EC}_{50}$ ) (Table 2). Beside DPPH method, total antioxidant capacity (TAC) of methanol extracts and essential oil was also evaluated. The TAC assay, which is a single assay sufficient for reliable determination of antioxidant potential of a complex sample, is based on the reduction of copper (II) to copper (I) by antioxidants [51]. TAC values were shown as mM reducing equivalents to uric acid (UAE) and as $\mu \mathrm{M}$ copper reducing equivalents (CRE) in Table 2.

Table 2. Antioxidant activity of essential oil and methanol extract of $A$. hamzaoglui *.

\begin{tabular}{cccc}
\hline \multirow{2}{*}{ Sample } & DPPH Scavenging Assay & \multicolumn{2}{c}{ Total Antioxidant Capacity } \\
\cline { 2 - 4 } & $\mathbf{E C}_{\mathbf{5 0}}(\boldsymbol{\mu} \mathbf{g} / \mathbf{m L})$ & $\mathbf{U A E}^{\mathbf{1}}(\mathbf{m M})$ & $\mathbf{C R E}^{\mathbf{2}}(\boldsymbol{\mu M})$ \\
\hline $\mathrm{AH}-\mathrm{EO}$ & - & $0.082 \pm 0.003$ & $179.50 \pm 6.57$ \\
$\mathrm{AH}-\mathrm{ME}$ & $32.09 \pm 1.98$ & $2.038 \pm 0.011$ & $4461.18 \pm 24.08$ \\
$\mathrm{BHT}$ & $29.83 \pm 1.23$ & - & - \\
\hline
\end{tabular}

*: Results are represented as means \pm standard deviation $(n=3) ;{ }^{1}$ : Uric acid equivalent, ${ }^{2}$ : Copper reducing equivalent.

As far as antioxidative potency of the samples is concerned, AH-ME was more effective in both DPPH and TAC assays. AH-ME reduced the stable free radical DPPH with a very low EC50 value $(32.09 \pm 1.98 \mu \mathrm{g} / \mathrm{mL})$, which was very similarto that of reference compound BHT $\left(\mathrm{EC}_{50}=29.83 \pm\right.$ $1.23 \mu \mathrm{g} / \mathrm{mL}$ ). $\mathrm{EC}_{50}$ value of AH-EO could not be calculated because of lower values of inhibition than $50 \%$. Total antioxidant capacity of AH-ME and AH-EO was measured as $2.038 \pm 0.011 \mathrm{UAE}$ and $0.082 \pm 0.003$ URE, respectively, showing that the AH-ME is 25-fold stronger than AH-EO.

In vitro antimicrobial activity of $\mathrm{AH}-\mathrm{EO}$ and $\mathrm{AH}-\mathrm{ME}$ against common Gram-positive and Gram-negative bacteria and standard Candida strains associated with human infections was assessed by using broth microdilution method [52,53]. Minimum inhibitory concentrations (MIC) of the test samples and standards are summarized in Table 3. According to the microdilution assay, AH-ME showed relatively weak antimicrobial effects against all tested bacteria (MIC; $0.625 \mathrm{mg} / \mathrm{mL}$ ) except Pseudomonas aeruginosa (MIC; $0.15625 \mathrm{mg} / \mathrm{mL}$ ). In comparison to Chloramphenicol, Clarithromycin 
and Tetracycline, AH-EO showed moderate to weak inhibitory effects (MIC; $0.15625-0.625 \mathrm{mg} / \mathrm{mL}$ ) against the tested bacteria, except Staphylococcus aureus (MIC; $0.07812 \mathrm{mg} / \mathrm{mL}$ ), which was strongly inhibited by AH-EO. Both AH-ME and AH-EO also showed moderate inhibitory effects on the Candida species (MIC; 0.15625-0.3125 mg/mL).

Previous investigations of Achillea species essential oils demonstrated mostly weak or moderate antimicrobial activity. As there is no data available about the activity of essential oil of $A$. hamzaoglui in the literature, antimicrobial activity can only be directly compared with chemically similar oils, composing at least the same major compounds. However, apart from chemical variations of essential oils, differences in methods applied and diversity of microorganisms used, make results incomparable. In light of these facts, antimicrobial activity of essential oils of some Achillea species containing 1,8-cineol as major component were given. Tzakou et al., reported that the best inhibitory effect of essential oils of the inflorescences and leaves of $A$. coarctata, which were characterized by the abundance of oxygenated monoterpenes 1,8-cineole (26.9\% and $29.1 \%$, respectively), camphor (22.1\%, 9.2\%) and borneol (5.0\% and 6.8\%, respectively), was detected against Micrococcus flavus, Enterococcus faecalis and C. albicans (MIC; $3.25 \mathrm{mg} / \mathrm{mL}$ ) [19]. According to literature survey, essential oils of $A$. setaceae and $A$. teretifolia, whose major oil was 1,8-cineol (18.5\% and 19.9\%, respectively), exhibited inhibitory effects on Clostridium perfringens, Acinetobacter lwoffii and C. albicans with a range of minimum inhibitory concentration values extended from 0.28 to $2.25 \mathrm{mg} / \mathrm{mL}$ [39]. In another study, water-soluble and water-insoluble fractions of methanol extract and essential oil of $\mathrm{A}$. millefolium, which contain 1,8-cineol (24.6\%), camphor (16.7\%), $\alpha$-terpineol (10.2\%), $\beta$-pinene (4.2\%), and borneol $(4.0 \%)$ as principal components, were tested against various microorganism. The essential oil possessed stronger antimicrobial activity than the extracts tested. The oil exhibited moderate activity against Streptococcus pneumoniae, Clostridium perfringens and C. albicans, and weak activity against Mycobacterium smegmatis, Acinetobacter lwoffii and C. krusei [25]. In addition, in contrary to our results, same authors also reported that the oil strongly reduced the DPPH radical $\left(\mathrm{IC}_{50}=1.56 \mu \mathrm{g} / \mathrm{mL}\right)$ while water-soluble part of methanol extract of the plant showed weaker radical scavenging ability $\left(\mathrm{IC}_{50}=45.60 \mu \mathrm{g} / \mathrm{mL}\right)$. In another study, it was reported that essential oils of $A$. teretifolia and A. vermicularis, which were investigated at various concentrations and incubation time, also showed considerable DPPH scavenging activity [18]. DPPH radical scavenging capacity of the floral infusions of $A$. biebersteinii, A. coarctata, A. kotschyi subsp. kotschyi, A. schischkinii, A. setacea, and A. teretifolia, which are growing in Turkey, were reported to be $33.5 \%, 23.9 \%, 27.4 \%, 33.6 \%, 27.4 \%$ and $28.7 \%$, respectively, while total antioxidant capacity of infusions, based on the reduction of Mo (VI) to Mo (V), were determined to be $8.419,4.671,5.599,8.419,6.999$ and $6.928 \mathrm{mM} \alpha$-Tocopherol/100 $\mathrm{mL}$, respectively [54]. In another study, ethanol extracts of aerial parts of Iranian A. millefolium, A. vermicularis and $A$. wilhelmsii exhibited DPPH radical scavening activity with $\mathrm{EC}_{50}=49.43, \mathrm{EC}_{50}=$ 85.28 and $\mathrm{EC}_{50}=118.90$ [55]. There are no previous data on the antioxidant potential of A. lycaonica and $A$. sintenisii extracts. 
Table 3. Antimicrobial activity of essential oil and methanol extract of $A$. hamzaoglui.

\begin{tabular}{|c|c|c|c|c|c|c|}
\hline \multirow{2}{*}{ Microorganisms } & \multicolumn{6}{|c|}{ MIC * $(\mu \mathrm{g} / \mathrm{mL})$} \\
\hline & AH-EO ${ }^{1}$ & AH-ME ${ }^{2}$ & Chloramphenicol & Clarithromycin & Tetracycline & Ketoconazole \\
\hline \multicolumn{7}{|l|}{ Bacteria } \\
\hline $\begin{array}{l}\text { Escherichia coli } \\
\text { (NRRL B3008) }\end{array}$ & 625 & 625 & 2 & - & - & - \\
\hline $\begin{array}{l}\text { Salmonella typhimurium } \\
\quad \text { (ATCC 13311) }\end{array}$ & 312.5 & 625 & 4 & - & - & - \\
\hline $\begin{array}{c}\text { Pseudomonas aeruginosa } \\
\text { (ATCC 10145) }\end{array}$ & 156.25 & 156.25 & 32 & - & - & - \\
\hline $\begin{array}{l}\text { Staphylococcus aureus } \\
\text { (ATCC BAA-1026) }\end{array}$ & 78.12 & 625 & 8 & - & - & - \\
\hline $\begin{array}{c}\text { Propionibacterium acnes } \\
\text { (ATCC 6919) }\end{array}$ & 156.25 & 625 & 4 & 0.25 & 1 & - \\
\hline $\begin{array}{l}\text { Streptococcus mitis } \\
\text { (NCIMB 13770) }\end{array}$ & 312.5 & 625 & 2 & 0.25 & 0.5 & - \\
\hline \multicolumn{7}{|l|}{ Fungi } \\
\hline $\begin{array}{l}\text { Candida krusei } \\
\text { (NRRLY 7179) }\end{array}$ & 312.5 & 312.5 & - & - & - & 0.5 \\
\hline $\begin{array}{l}\text { Candida albicans } \\
\text { (ATCC 24433) }\end{array}$ & 312.5 & 312.5 & - & - & - & 0.25 \\
\hline $\begin{array}{l}\text { Candida tropicalis } \\
\text { (ATCC 1369) }\end{array}$ & 312.5 & 312.5 & - & - & - & 0.25 \\
\hline $\begin{array}{l}\text { Candida parapsilosis } \\
\text { (ATCC 22019) }\end{array}$ & 312.5 & 156.25 & - & - & - & 0.25 \\
\hline
\end{tabular}

* Minimum inhibition concentrations, ${ }^{1}$ A. hamzaoglui essential oil, ${ }^{2}$ A. hamzaoglui methanol extract. 
Natural antioxidants are generally more desirable for consumption than synthetic ones because these natural antioxidants avoid the toxicity problems which may arise from the use of synthetic antioxidants, such as butylated hydroxy anisole (BHA) and butylated hydroxy toluene (BHT) [49]. Therefore, in order to find new sources of safe antioxidants of natural origin, plant extracts have been extensively searched for their antioxidant and radical scavenging properties. In the present study, AH-ME exhibited distinctively strong DPPH radical scavenging activity with a $\mathrm{EC}_{50}=32.09 \pm 1.98 \mu \mathrm{g} / \mathrm{mL}$ as well as high total antioxidant capacity $(2.038 \pm 0.011 \mathrm{UAE})$ when compared our results with previous data on Achillea species.

\section{Experimental Section}

\subsection{Plant Material}

The plants were collected during the flowering stage from different provinces of inner Anatolia. The collected samples were identified and the voucher specimens were deposited in the Herbarium of Hacettepe University, Faculty of Pharmacy (HUEF) and Herbarium of Hacettepe University Faculty of Education (HEF). Information concerning the plant material is given in Table 4.

Table 4. Herbaria records of Achillea species.

\begin{tabular}{|c|c|c|c|}
\hline Achillea sp. & Collection Site and Altitude & $\begin{array}{l}\text { Collection } \\
\text { Period }\end{array}$ & $\begin{array}{l}\text { Specimen } \\
\text { Number * }\end{array}$ \\
\hline A. biebersteinii & $\begin{array}{l}\text { A4 Ankara: Beytepe Campus, the road into the forest, } \\
\qquad 39^{\circ} 52^{\prime} 40^{\prime \prime} \mathrm{N}, 32^{\circ} 43^{\prime} 49^{\prime \prime} \mathrm{E}, 992 \mathrm{~m}\end{array}$ & 26 June 2014 & $\begin{array}{l}\text { HUEF } \\
14053\end{array}$ \\
\hline A. coarctata & $\begin{array}{l}\text { B5 Nevşehir: Nevşehir to Aksaray, } 2 \mathrm{~km} \text { to Camiören village, } \\
\qquad 38^{\circ} 30^{\prime} 15^{\prime \prime} \mathrm{N}, 34^{\circ} 23^{\prime} 19^{\prime \prime} \mathrm{E}, 1220 \mathrm{~m}\end{array}$ & 22 July 2013 & $\begin{array}{l}\mathrm{HEF} \\
15093\end{array}$ \\
\hline A. hamzaoglui & $\begin{array}{l}\text { B5 Kırşehir: Kırşehir to Mucur, Kervansaray Mountain, junction } \\
\text { of Bahçecik, Mehtap Hill, } 39^{\circ} 08^{\prime} 22^{\prime \prime} \mathrm{N}, 34^{\circ} 17^{\prime} 46^{\prime \prime} \mathrm{E}, 1350 \mathrm{~m}\end{array}$ & 1 June 2013 & $\begin{array}{l}\text { HEF } \\
14970\end{array}$ \\
\hline $\begin{array}{l}\text { A. kotschyi } \\
\text { subsp. kotschyi }\end{array}$ & $\begin{array}{l}\text { B6 Yozgat: Akdağmadeni, above Kizılcaova village, Nalbant hill, } \\
\qquad 39^{\circ} 31^{\prime} 14^{\prime \prime} \mathrm{N}, 36^{\circ} 01^{\prime} 20^{\prime \prime} \mathrm{E}, 2000 \mathrm{~m}\end{array}$ & 1 July 2014 & $\begin{array}{l}\text { HUEF } \\
14044\end{array}$ \\
\hline A. lycaonica & B6 Sivas: Ulaş, Ziyarettepe, $39^{\circ} 32^{\prime} 44^{\prime \prime} \mathrm{N}, 37^{\circ} 02^{\prime} 11^{\prime \prime} \mathrm{E}, 1450 \mathrm{~m}$ & 24 July 2013 & $\begin{array}{l}\mathrm{HEF} \\
15095\end{array}$ \\
\hline $\begin{array}{l}\text { A. millefolium } \\
\text { subsp. millefolium }\end{array}$ & $\begin{array}{c}\text { B6 Yozgat: Akdağmadeni, Karababa mountain, South of Çerçialan } \\
\text { village, } 39^{\circ} 32^{\prime} 27^{\prime \prime} \mathrm{N}, 36^{\circ} 06^{\prime} 60^{\prime \prime} \mathrm{E}, 1880 \mathrm{~m}\end{array}$ & $\begin{array}{l}4 \text { August } \\
2014\end{array}$ & $\begin{array}{l}\text { HUEF } \\
14047\end{array}$ \\
\hline A. schischkinii & $\begin{array}{c}\text { B6 Sivas: Şerefiye, Karabayır Passage, } 40^{\circ} 09^{\prime} 50^{\prime \prime} \mathrm{N}, 37^{\circ} 50^{\prime} 53^{\prime \prime} \mathrm{E} \text {, } \\
1925 \mathrm{~m}\end{array}$ & 25 July 2013 & $\begin{array}{l}\text { HEF } \\
15097\end{array}$ \\
\hline A. setacea & 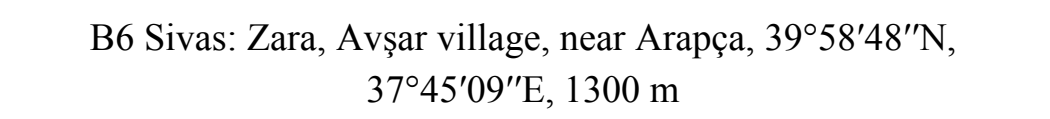 & 6 July 2014 & $\begin{array}{l}\text { HUEF } \\
14046\end{array}$ \\
\hline A. sintenisii & B6 Sivas: Ulaş, Ziyarettepe, $39^{\circ} 33^{\prime} 41^{\prime \prime} \mathrm{N}, 37^{\circ} 00^{\prime} 52^{\prime \prime} \mathrm{E}, 1430 \mathrm{~m}$ & 7 July 2014 & $\begin{array}{l}\text { HUEF } \\
14056\end{array}$ \\
\hline A. vermicularis & $\begin{array}{l}\text { B9 Van: Van-Bahçesaray yolu, Sisar deresi mevkii, } 38^{\circ} 15^{\prime} 51^{\prime \prime} \mathrm{N} \\
43^{\circ} 10^{\prime} 23^{\prime \prime} \mathrm{E}, 2015 \mathrm{~m}\end{array}$ & 12 July 2013 & $\begin{array}{l}\text { HUEF } \\
13013\end{array}$ \\
\hline $\begin{array}{l}\text { A. wilhelmsii } \\
\text { subsp. wilhelmsii }\end{array}$ & $\begin{array}{l}\text { C5 Niğde: Ovacık village, Ovacık-Çamardı road, } 38^{\circ} 06^{\prime} 07^{\prime \prime} \mathrm{N}, \\
\qquad 34^{\circ} 49^{\prime} 17^{\prime \prime} \mathrm{E}, 1350 \mathrm{~m}\end{array}$ & 9 July 2014 & $\begin{array}{l}\text { HUEF } \\
14050 \\
\end{array}$ \\
\hline
\end{tabular}

* HUEF: Herbarium of Hacettepe University Faculty of Pharmacy, HEF: Herbarium of Hacettepe University Faculty of Education. 


\subsection{Isolation of Essential Oil and Extraction}

The air-dried aerial parts of the plant material were hydrodistilled for $3 \mathrm{~h}$ using a Clevenger-type apparatus to produce a small amount $(<0.01 \%)$ of volatiles, which was trapped in $n$-hexane. Air-dried and ground plant material of $A$. hamzaoglui were subjected to hydrodistillation for $3 \mathrm{~h}$ using a Clevenger-type apparatus to obtain essential oil in $0.07 \%$ yield. All samples were stored at $4{ }^{\circ} \mathrm{C}$ in the dark until analyzed. Twenty grams of plant material was also extracted with methanol three times at $40{ }^{\circ} \mathrm{C}$ and methanol was evaporated under reduced pressure (yield $11.6 \% \mathrm{w} / \mathrm{w}$ ).

\subsection{Gas Chromatography Analysis}

The GC analysis was carried out using an Agilent 6890N GC system. FID detector temperature was $300{ }^{\circ} \mathrm{C}$. To obtain the same elution order with GC/MS, simultaneous auto injection was done on a duplicate of the same column applying the same operational conditions. Relative percentage amounts of the separated compounds were calculated from FID chromatograms.

\subsection{Gas Chromatography-Mass Spectrometry Analysis}

The GC/MS analysis was carried out with an Agilent 5975 GC/MSD system. Innowax FSC column $(60 \mathrm{~m} \times 0.25 \mathrm{~mm}, 0.25 \mu \mathrm{m}$ film thickness $)$ was used with helium as carrier gas $(0.8 \mathrm{~mL} / \mathrm{min})$. GC oven temperature was kept at $60{ }^{\circ} \mathrm{C}$ for $10 \mathrm{~min}$ and programmed to $220{ }^{\circ} \mathrm{C}$ at a rate of $4{ }^{\circ} \mathrm{C} / \mathrm{min}$, and kept constant at $220{ }^{\circ} \mathrm{C}$ for $10 \mathrm{~min}$ and then programmed to $240{ }^{\circ} \mathrm{C}$ at a rate of $1{ }^{\circ} \mathrm{C} / \mathrm{min}$. Split ratio was adjusted at 40:1. The injector temperature was set at $250^{\circ} \mathrm{C}$. Mass spectra were recorded at $70 \mathrm{eV}$. Mass range was from $m / z 35$ to 450 .

\subsection{Identification of Components}

Identification of the oil components was carried out by comparison of their relative retention times with those of authentic samples or by comparison of their relative retention index (RRI) to series of n-alkanes. Computer matching against commercial (Wiley and MassFinder 3) [56,57] and in-house "Başer Library of Essential Oil Constituents" built up by genuine compounds and components of known oils, as well as MS literature data [58] were also used for the identification.

\subsection{Antioxidant Activity}

\subsubsection{DPPH Radical Scavenging Assay}

The free radical scavenging activity of the fractions was measured in vitro by 2,2'-diphenyl-1-picrylhydrazyl (DPPH) assay according to the method described earlier [50]. The stock solution was prepared by dissolving $24 \mathrm{mg}$ DPPH (Sigma-Aldrich, St. Louis, MO, USA) with $100 \mathrm{~mL}$ methanol and stored at $20{ }^{\circ} \mathrm{C}$ until required. The working solution was obtained by diluting DPPH solution with methanol to attain an absorbance of about $0.98 \pm 0.02$ at $517 \mathrm{~nm}$ using the spectrophotometer. A $3 \mathrm{~mL}$ aliquot of this solution was mixed with $100 \mu \mathrm{L}$ of the sample at various concentrations $(1-150 \mu \mathrm{g} / \mathrm{mL})$. The reaction mixture was shaken well and incubated in the dark for 30 
min at room temperature. Then the absorbance was taken at $517 \mathrm{~nm}$. The scavenging activity was estimated based on the percentage of DPPH radical scavenged as the following equation:

$$
\mathrm{DPPH} \text { radical scavenging activity }(\%)=\left[\left(\mathrm{A}_{0}-\mathrm{A}_{1}\right) / \mathrm{A}_{0}\right] \times 100
$$

A0: Absorbance of the control at $30 \mathrm{~min}(517 \mathrm{~nm}) ; \mathbf{A}_{1}$ : Absorbance of the sample at $30 \mathrm{~min}(517 \mathrm{~nm})$. BHT (Sigma-Aldrich) was used as a positive control. Tests were carried out in triplicate. Afterwards, a curve of $\% \mathrm{DPPH}$ scavenging capacity versus concentration was plotted and $\mathrm{EC}_{50}$ values were calculated. $\mathrm{EC}_{50}$ denotes the concentration of sample required to scavenge $50 \%$ of DPPH free radicals.

\subsubsection{Total Antioxidant Capacity (TAC) Assay}

The assay was carried out using commercial TAC assay kit (OxiSelect ${ }^{\mathrm{TM}}$ Total Antioxidant Capacity (TAC) Assay Kit, Cell Biolabs, Inc., San Diego, CA, USA). Upon reduction, the copper (I) ion further reacts with a coupling chromogenic reagent that produces a color with a maximum absorbance at $490 \mathrm{~nm}$. The net absorbance values of antioxidants are compared with a known uric acid standard curve. Absorbance values are proportional to the sample's total reductive capacity. Results are expressed as $\mu \mathrm{M}$ copper reducing equivalents or $\mathrm{mM}$ uric acid equivalents. A fresh uric acid standard was prepared by weighing out the uric acid powder for a $10 \mathrm{mg} / \mathrm{mL}$ solution in $1 \mathrm{~N} \mathrm{NaOH}$. This $10 \mathrm{mg} / \mathrm{mL}$ is equivalent to a concentration of $60 \mathrm{mM}$. The $60 \mathrm{mM}$ uric acid solution was used to prepare a $2 \mathrm{mM}$ solution of uric acid (e.g., add $100 \mu \mathrm{L}$ of the $60 \mathrm{mM}$ uric acid standard to $2.9 \mathrm{~mL}$ of deionized water). Each sample was prepared using the stock solution of $100 \mathrm{mg} / \mathrm{mL}$ concentration. An initial reading was taken at $490 \mathrm{~nm}$. Then, $50 \mu \mathrm{L}$ of the $1 \times$ copper ion reagent was added and incubated for 5 min on an orbital shaker. Then, $50 \mu \mathrm{L}$ of the stop solution was added to terminate the reaction and the plate was read again at $490 \mathrm{~nm}$. All determinations were performed in triplicate and results were averaged.

\subsection{Antimicrobial Activity}

\subsubsection{Test Microorganisms}

Microorganisms were obtained from ATCC, NRRL or clinical isolates (Eskişehir Osmangazi University, Turkey; Anadolu University, Faculty of Science, Department of Biology, Eskişehir, Turkey) and were stored in $15 \%$ glycerol containing micro-test tubes at $-86^{\circ} \mathrm{C}$ (strain numbers of microorganisms were given in Table 3). All microorganism strains were inoculated on Mueller Hinton Agar (MHA) or Sabouraud Dextrose Agar (SDA) prior the experiments at $37^{\circ} \mathrm{C}$. After sufficient growth, the microorganisms were transferred to Mueller Hinton Broth (MHB) for further incubation at the same conditions for another $24 \mathrm{~h}[52,53]$.

\subsubsection{Broth Microdilution Assay}

Test samples as well as standard antimicrobial controls were first dissolved in DMSO (25\%) at an initial concentration. Serial dilution series were prepared in $100 \mu \mathrm{L}$ Mueller Hinton Broth (MHB) with an equal amount of the test samples. Overnight grown microorganism suspensions at appropriate conditions were first diluted in double strength $\mathrm{MHB}$ and standardized turbitometrically to $1 \times 510^{6}-10^{8} \mathrm{CFU} / \mathrm{mL}$ (McFarland No: 0.5) under sterile conditions. Then each microorganism suspension was pipetted into 
each well and incubated at $37^{\circ} \mathrm{C}$ for $24 \mathrm{~h}$. Sterile distilled water and medium served as a positive growth control. The first well without turbidity was assigned as the minimum inhibitory concentration (MIC, in $\mu \mathrm{g} / \mathrm{mL}$ ). To visualize the antimicrobial activity Tetrazolium Violet 1\% (w/v, EtOH) (2,5-diphenyl-3-[ $\alpha$ naphthyl] tetrazolium chloride, TTC, Sigma) was also used. Average results of separately performed three experiments were given $[52,53]$.

\subsection{Statistical Analysis}

The essential oils components useful in reflecting chemotaxonomic and biological relationships, compounds detected in oil samples with an average concentration of greater than $0.6 \%$ were selected. The components were subjected to a principal component analysis (PCA) and to hierarchical cluster analysis (HCA) using IBM SPSS software version 22.0.

\section{Conclusions}

In this study, we investigated essential oil compositions of A. hamzaoglui along with ten Achillea species growing in Turkey, which is one of the main diversity centers of the genus Achillea. With regard to their essential oil composition, PCA and HCA analysis enabled to identify three groups and a subgroup of Achillea species, where each group constituted a chemotype.

There is a widespread agreement that synthetic antioxidants need to be replaced with natural ones because some synthetic antioxidants have shown potential health risks and toxicity. Therefore, in order to find new sources of safe antioxidants of natural origin, a great interest has been given to the antioxidant and radical scavenging properties of plant extracts. In the present study, A. hamzaoglui methanol extract exhibited very strong radical scavenging activity and high antioxidant capacity. The findings indicate that methanol extract of A. hamzaoglui can be considered a rich natural source of antioxidants that could be used in pharmaceutical preparations, cosmetics and foods. On the other hand, essential oil of the plant exhibited much more prominent antimicrobial activity against tested microorganisms than that of methanol extract. Because of its strong antibacterial activity against Staphylococcus aureus (ATCC BAA-1026) and moderate antibacterial activity against Pseudomonas aeruginosa (ATTC 10145) and Propionibacterium acnes (ATCC 6919), the essential oil could be effectively used for skin infections. This study is the first report on essential oil composition and antioxidant and antimicrobial activities of A. hamzaoglui, and calls for further investigations to elucidate its effect on other biological activities.

\section{Acknowledgments}

Present work was supported by a grant from Hacettepe University Scientific Research Projects Coordination Unit (Project No: 014 D06 301 003).

\section{Author Contributions}

F.P.T and B.D. designed the study. F.P.T., O.T.A. and G.A. collected plant samples. F.P.T performed antioxidant activity tests. B.T. performed antimicrobial activity tests and the chemical analysis. M.H. performed cluster analysis. F.P.T. and B.D. interpreted the results. F.P.T. wrote the manuscript. All authors read and approved the manuscript. 


\section{Conflicts of Interest}

The authors declare no conflict of interest.

\section{References}

1. Nemeth, E. Achillea species used medicinally in Hungary. Israel J. Plant Sci. 2010, 58, 279-289.

2. Huber-Morath, A. Achillea L. In Flora of Turkey and the East Aegean Islands; Davis, P.H., Ed.; Edinburgh University Press: Edinburgh, UK,1975; Volume 5, pp. 224-252.

3. Duman, H. Achillea L. In Flora of Turkey and the East Aegean Islands; Güner, A., Özhatay, N., Ekim, T., Başer, K.H.C., Eds.; Edinburgh University Press: Edinburgh, UK, 2000; Volume 11, pp. $158-159$.

4. Arabaci, T.; Budak, Ü. Achillea hamzaoglui (Asteraceae)a new species from Turkey. Ann. Bot. Fennici 2009, 46, 459-463.

5. Nemeth, E.; Bernath, J. Biological activities of yarrow species (Achillea spp.). Curr. Pharm. Design 2008, 14, 3151-3167.

6. Hoffman, D. Medical Herbalism, The Science and Practice of Herbal Medicine; Healing Art Press: Rochester, Vermont, 2003; p. 622.

7. Baytop, T. Türkiye'de Bitkilerle Tedavi; Nobel Tip Kitabevi, Ankara, Turkey, 1999; pp. 176-177.

8. Ezer, N.; Arısan, Ö.M. Folk Medicines in Merzifon (Amasya, Turkey). Turk. J. Bot. 2006, 30, 223-230.

9. Honda, G.; Yeşilada, E.; Tabata, M.; Sezik, E.; Fujita, T.; Takeda, Y.; Takaishi, Y.; Tanaka, T. Traditional medicine in Turkey VI. Folk medicine in West Anatolia: Afyon, Kutahya, Denizli, Mugla, Aydin provinces. J. Ethnopharmacol. 1996, 53, 75-87.

10. Tuzlaci, E.; Erol, M.K. Turkish folk medicinal plants. Part II: Eğirdir (Isparta). Fitoterapia 1999, 70, 593-610.

11. Sezik, E.; Yeşilada, E.; Honda, G.; Takaishi, Y.; Takeda, Y.; Tanaka, T. Traditional medicine in Turkey X. Folk medicine in Central Anatolia. J. Ethnopharmacol. 2001, 75, 95-115.

12. Saeidnia, S.; Gohari, A.R.; Mokhber-Dezfuli, N.; Kiuchi, F. A review on phytochemistry and medicinal properties of the genus Achillea. Daru 2011, 19, 173-186.

13. Vitalini, S.; Iriti, M.; Puricelli, C.; Ciuchi, D.; Segale, A.; Fico, G. Traditional knowledge on medicinal and food plants used in Val San Giacomo (Sondrio, Italy)-An alpine ethnobotanical study. J. Ethnopharmacol. 2013, 145, 517-529.

14. Si, X.T.; Zhang, M.L.; Shi, Q.W.; Kiyota, H. Chemical constituents of the plants in the genus Achillea. Chem. Biodivers. 2006, 3, 1163-1180.

15. Nemeth, E. Essential Oil Composition of Species in the Genus Achillea. J. Essent. Oil Res. 2005, 17, 501-512.

16. Radulovic, N.; Zlatkovic, B.; Palic, R.; Stojanovic, G. Chemotaxonomic significance of the Balkan Achillea volatiles. Nat. Prod. Commun. 2007, 2, 453-474.

17. Guo, Y.P.; Ehrendorfer, F.; Samuel, R. Phylogeny and systematics of Achillea (AsteraceaeAnthemideae) inferre from nrITS and plastid trnL-F DNA sequences. Taxon 2004, 53, 657-672. 
18. Polatoglu, K.; Karakoc, O.C.; Goren, N. Phytotoxic DPPH scavenging, insecticidal activities and essential oil composition of Achillea vermicularis, A. teretifolia and proposed chemotypes of A. biebersteinii (Asteraceae). Ind. Crop. Prod. 2013, 51, 35-45.

19. Tzakou, O.; Couladis, M.; Milenkovic, M.; Vucicevic, D.; Kovacevic, N. Composition and Antimicrobial Activity of Achillea coarctata Essential Oils from Greece. J. Essent. Oil Bear. Pl. 2009, 12, 541-545.

20. Toker, Z.; Ozen, H.C.; Clery, R.A.; Owen, N.E. Essential oils of two Achillea species from Turkey. J. Essent. Oil Res. 2003, 15, 100-101.

21. Karamenderes, C.; Karabay, N.Ü.; Zeybek, U. Composition and antimicrobial activity of the essential oils of some Achillea species in Turkey. Acta Pharm. Turc. 2002, 44, 221-225.

22. Azaz, A.D.; Arabaci, T.; Sangun, M.K.; Yildiz, B. Composition and the in vitro antimicrobial activities of the essential oils of Achillea wilhelmsii C. Koch. and Achillea lycaonica Boiss \& Heldr. Asian J. Chem. 2008, 20, 1238-1244.

23. Baser, K.H.C.; Demirci, B.; Duman, H. Composition of the essential oils of two endemic species from Turkey: Achillea lycaonica and A. ketenoglui. Chem. Nat. Compd. 2001, 37, 245-252.

24. Kocak, A.; Bagci, E.; Bakoglu, A. Chemical composition of essential oils of Achillea teretifolia Willd. And A. millefolium L. subsp. millefolium growing in Turkey. Asian J. Chem. 2010, 22, 3653-3658.

25. Candan, F.; Unlu, M.; Tepec, B.; Daferera, D.; Polissiou, M.; Sökmen, A.; Akpulat, H.A. Antioxidant and antimicrobial activity of the essential oil and methanol extracts of Achillea millefolium subsp. millefolium Afan. (Asteraceae). J. Ethnopharmacol. 2003, 87, 215-220.

26. Falconieri, D.; Piras, A.; Porcedda, S.; Marongiu, B.; Gonçalves, M.J.; Cabral, C.; Cavaleiro, C.; Salgueiro, L. Chemical Composition and Biological Activity of the Volatile Extracts of Achillea millefolium. Nat. Prod. Commun. 2011, 6, 1527-1530.

27. Tuberoso, C.; Kowalczyk, A. Chemical composition of the essential oils of Achillea millefolium L. isolated by different distillation methods. J. Essent. Oil Res. 2009, 21, 108-111.

28. Bocevska, M.; Sovova, H. Supercritical $\mathrm{CO}_{2}$ extraction of essential oil from yarrow. J. Supercrit. Fluids 2007, 40, 360-367.

29. Smelcerovic, A.; Lamshoeft, M.; Radulovic, N.; Ilic, D.; Palic, R. LC-MS analysis of the essential oils of Achillea millefolium and Achillea crithmifolia. Chromatographia 2010, 71, 113-116.

30. Orav, A.; Kailas, T.; Ivask, K. Composition of the essential oil from Achillea millefolium L. from Estonia. J. Essent.Oil Res. 2001, 13, 290-294.

31. Mockute, D.; Judzentiene, A. Variability of the essential oils composition of Achillea millefolium ssp. Millefolium growing wild in Lithuania. Biochem. Syst. Ecol. 2003, 31, 1033-1045.

32. Azizi, M.; Chizzola, R.; Ghani, A.; Oroojalian, F. Composition at different development stages of the essential oil of four Achillea species grown in Iran. Nat. Prod. Commun. 2010, 5, 283-290.

33. Barghamadi, A.; Mehrdad, M.; Sefidkon, F.; Yamini, Y.; Khajeh, M. Comparison of the Volatiles of Achillea millafolium L. Obtained by supercritical carbon dioxide extraction and hydrodistillation methods. J. Essent. Oil Res.2009, 21, 259-263.

34. Suleimenov, Y.M.; Atazhanova, G.A.; Ozek, T.; Demirci, B.; Kulyyasov, A.T.; Adekenov, S.M.; Baser, K.H.C. Essential oil composition of three species of Achillea from Kazakhstan. Chem. Nat. Compd. 2001, 37, 447-450. 
35. Shawl, A.S.; Srivastava, S.K.; Syamasundar, K.V.; Tripathi, S.; Raina, V.K. Essential oil composition of Achillea millefolium L. growing wild in Kashmir, India. Flavour Frag. J. 2001, 17, 165-168.

36. Agnihotri, V.K.; Lattoo, S.K.; Thappa, R.K.; Kaul, P.; Qazi, G.N.; Dhar, A.K.; Saraf, A.; Kapahi, B.K.; Saxena, R.K.; Agarwal, S.G. Chemical variability in the essential oil components of Achillea millefolium Agg. from different Himalayan habitats (India). Planta Med. 2005, 71, 280-283.

37. Donmez, E.; Tepe, B.; Daferera, D.; Polissiou, M. Composition of the essential oil of Achillea schischkinii Sosn. (Asteraceae) from Turkey. J. Essent. Oil Res. 2005, 17, 575-576.

38. İşcan, G.; Kırımer, N.; Kurkçuoglu, M.; Arabacı, T.; Kupeli, E.; Baser, K.H.C. Biological activity and composition of the essential oils of Achillea schischkinii Sosn. and Achillea aleppica DC. subsp. aleppica. J. Agric. Food Chem. 2006, 54, 170-173.

39. Unlu, M.; Daferera, D.; Donmez, E.; Polissiou, M.; Tepe, B.; Sokmen, A. Compositions and the in vitro antimicrobial activities of the essential oils of Achillea setacea and Achillea teretifolia (Compositae). J. Ethnopharmacol. 2002, 83, 117-121.

40. Sokmen, A.; Vardar-Unlu, G.; Polissiou, M.; Daferera, D.; Sokmen, M.; Donmez, E. Antimicrobial activity of essential oil and methanol extracts of Achillea sintenisii Hub. Mor. (Asteraceae). Phytother. Res. 2003, 17, 1005-1010.

41. Rustaiyan, A.; Komeilizadeh, H.; Shariatpanahi, M.S.; Jassbi, A.; Masoudi, S. Comparative study of the essential oils of three Achillea species from Iran. J. Essent. Oil Res. 1998, 10, 207-209.

42. Ghani, A.; Azizi, M.; Hassanzadeh-Khayyat, M.; Pahlavanpour, A.A. Essential oil composition of Achillea eriophora, A. nobilis, A. biebersteinii and A. wilhelmsii from Iran. J. Oil Bear. Pl. 2008, 11, 460-467.

43. Ghani, A.; Azizi, M.; Hassanzadeh-Khayyat, M.; Pahlavanpour, A.A. Comparison of Chemical Composition of Achillea eriophora and A. wilhelmsii Grown in Wild and Cultivated Conditions in Iran. J. Essent. Oil Bear. Pl. 2013, 14, 617-624.

44. Azadbakht, M.; Morteza-semnani, K.; Khansari, N. The essential oils composition of Achillea wilhelmsii C. Koch. Leaves and flowers. J. Med. Plants 2003, 2, 55-59.

45. Javidnia, K.; Miri, R.; Pour, S.H. Composition of the volatile oil of Achillea wilhelmsii C. Koch. from Iran. Daru 2004, 12, 63-66.

46. Jaimand, K.; Rezaee, M.B. Comparative study of the essential oils of three Achilea species from Iran. J. Essent. Oil Res. 2001, 13, 354-356.

47. Kindlovits, S.; Nemeth, E. Source of variability of Yarrow (Achillea spp.) Essential oil. Acta Aliment. 2012, 41, 92-103.

48. Rajendran, P.; Nandakumar, N.; Rengarajan, T.; Palaniswami, R.; Gnanadhas, E.N.; Gopas, J.; Lakshminarasaiah, U.; Nishigaki, I. Antioxidants and human diseases. Clin. Chim. Acta 2014, 25, 332-347.

49. Brewer, M.S. Natural Antioxidants: Sources, Compounds, Mechanisms of Action, and Potential Applications. Compr. Rev. Food Sci. F. 2011, 10, 221-247.

50. Brand-Williams, W.; Cuvelier, M.E.; Berset, C. Use of a Free-Radical Method to Evaluate Antioxidant Activity. Food Sci. Technol. Leb. 1995, 28, 25-30.

51. Özyürek, M.; Güçlü, K.; Apak, R. The main and modified CUPRAC methods of antioxidant measurement. TrAC Trend. Anal. Chem. 2011, 30, 652-664. 
52. Winn, C.W.; Allen, S.D.; Janda, W.M.; Koneman, E.; Procop, G.; Schreckenberger, P.; Woods, G. Koneman's Color Atlas and Textbook of Diagnostic Microbiology; Lippincott-Raven Pub.: Philadelphia, PA, USA, 2006; pp. 945-1021.

53. Iscan, G.; Kirimer, N.; Kurkcuoglu, M.; Baser, K.H.C.; Demirci, F. Antimicrobial screening of Mentha piperita essential oils. J. Agric. Food Chem. 2002, 50, 3943-3946.

54. Konyalıoğlu, S.; Karamenderes, C. Screening of total phenol contents ans antioxidant capacities of some Achillea L. species growing in Turkey. Acta Pharm. Turc. 2004, 46, 163-170.

55. Nickavar, B.; Kamalinejad, M.; Haj-Yahya, M.; Shafaghi, B. Comparison of the Free Radical Scavenging Activity of Six Iranian Achillea. Species. Pharm. Biol. 2006, 44, 208-212.

56. McLafferty, F.W.; Stauffer, D.B. The Wiley/NBS Registry of Mass Spectral Data; J Wiley and Sons: New York, NY, USA, 1989.

57. König, W.A.; Joulain, D.; Hochmuth, D.H. Terpenoids and Related Constituents of Essential Oils, 3rd ed.; MassFinder3: Hamburg, Germany, 2004.

58. Joulain, D.; König, W.A. The Atlas of Spectra Data of Sesquiterpene Hydrocarbons; EB-Verlag: Hamburg, Germany, 1998.

Sample Availability: Samples of the oils are available from the authors.

(C) 2015 by the authors; licensee MDPI, Basel, Switzerland. This article is an open access article distributed under the terms and conditions of the Creative Commons Attribution license (http://creativecommons.org/licenses/by/4.0/). 